Monika Horstmann · Anand Mishra 1

Meaning in the Structure of the Bhägavata Puräng
Anand Mishra 7

Ethics and Aesthetics in Early Modern South Asia: A Controversy Surrounding the Tenth Book of the Bhägavata Puräna
Kivokazu OKita 25

Śrīmad-Bhägavata-Pārāyanạ-Vidhi-Prakāasa: An Early Modern Poetry Workshop?

Heidi Pauwels 4

Black Curls in a Mirror: The Eighteenth-Century Persian Kṛṇa of Lāla Amānat

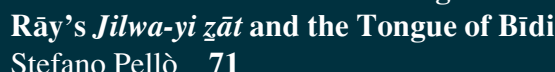

Krsna Goes to War: Translating the Bhägavata's Battle Scenes

Three Brajbhāāā Versions of the Bhägavata Purāna
Monika Horstmann 123

Mras

Translators' Troubles: Seeking a Method that Suits the Bhägavata Puräna

International Journal of

HINDU STUDIES

Edited by

Sushil Mittal

Special Issue: Transcreating the Bhägavata Purāna 


\title{
Black Curls in a Mirror: The Eighteenth-Century Persian Kṛ̣ṇa of Lāla Amānat Rāy's Jilwa-yi żăt and the Tongue of Bīdil
}

\author{
Stefano Pellò
}

Published online: 12 March 2018

(C) Springer Science+Business Media B.V., part of Springer Nature 2018

\begin{abstract}
This paper is the first substantial study of the Jilwa-yi $\underline{z} \bar{a} t$, an unabridged Persian verse translation of the tenth skandha of the Bhāgavata Purāna, completed in Delhi in 1732-33 by Amānat Rāy, a Vaiṣnava pupil of the influential poetphilosopher Mīrzā 'Abd al-Qādir Bīdil. The paper focuses especially on the textualization of Krṣna and Kṛ̣naite devotion within the framework of Persian literary conventions and the dominant Șūfī-Vedāntic conceptual atmosphere, with a special attention for the intertextual ties with the works of Bīdil. A few philological remarks on the contours of a hitherto largely ignored Krṣnaite subjectivity in Persian are also included.
\end{abstract}

Keywords Amānat Rāy $\cdot$ Bīdil $\cdot$ Kṛ̣ṇa $\cdot$ Bhāgavata Purāna $\cdot$ Persian translation

In the first chapter of his Haft tamāshā, "The Seven Views," a doxographic work completed in the early 1800 s and devoted primarily to an articulate description of the beliefs and religious habits of various communities of Hindus and Indian Muslims, Mīrzā Muḥammad Hasan Qatīl, while dealing with the "creed" (mazhab) of the Smārtas (samartgān) and the "cult" of the eighth avatāra (avatār-i hashtum) Kṛ̣ṇa (kishn), writes:

The capital city of Kanhaiyā is the town of Mathurā....In a large qaṣba called Gokul, at a distance of two karohs from Mathurā, lies a place called Bindāban....These two cities, that is, Mathurā and Bindāban, are set on the bank of a river named Jumnā and are the house of pleasure ('ishratkada) of Kanhaiyā. Hindūs (hinduwān) call Ban the territory between Bindāban and

Stefano Pellò

pello@unive.it

Ca'Foscari University of Venice, Venice, Italy 
Mathurā. In Hindī, ban means "open field" (maydān wa șaḥrā), but this is only its literal meaning: in fact, not every wilderness can be called ban, the term being technically used by Hindūs to refer exclusively to this place.... According to their creed (mazhab), this forest (jangal) called Ban provides

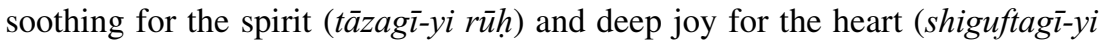
$d i l)$. The land where this forest lies is called Birj..., and the whole region is considered to be the ground of love and the terrain of affection (khäk-i 'ishq wa zamin-i mahabbat) (1875: 16).

Qatīl, who is writing in Lucknow for an Iranian audience (1875: 4), is not only expressing a cultic truth by recalling several immediately recognizable lexical and metaphorical features of the codified mainstream tradition of Persian lyrical poetry ('ishratkada, tāzagī-yi rūh, shiguftagī-yi dil, khāk-i 'ishq, zamīn-i mahabbat, a few lines later 'ayshgāh, ma'shūqa, 'āshiq, and so on). A Bhandārī Khatrī from a prominent munshī family, who had converted to Twelver Shī'ism at a young age, ${ }^{1}$ Qatīl is actually reconnecting to a whole set of late seventeenth- and especially eighteenth-century Indo-Persian texts, from tazkiras to mașnawīs, where the bliss of the Braj mandal and the amorous deeds of Krṣna had already carved out a specific place for themselves, enlarging the inclusive repertoire from within. ${ }^{2}$

As variously claimed in recent times, one of the "new horizons"- to use Muzaffar Alam and Sanjay Subrahmanyam's (2012) expression—conquered by the eighteenth-century Khatrī and Kāyastha writers of Persian is the organization of a noncontrasting self-representational and self-promotional space, both as Vaiṣnava and Persianate intellectuals, within the textual reality of Indo-Persian literary culture. As Qatîl's receptive observations aptly suggest, a non secondary aspect of this process of self-projection — aesthetical as much as historical—is easily the rich output of Persian poetic translations, rewritings, and original compositions referring to the Indic religious environment authored by Hindu munshis during the eighteenth century, already noted by Aziz Ahmad in the 1960s (Ahmad 1964: 235) and substantially overlooked up to now. The principal question I am posing here is whether and how we can begin to speak of Vaiṣnava textuality within this specific framework textured by change and newness, as well as by the confidence of munshis in making their own use of received literary models. In other words, if categorization is meaningful, then I would like to add a fifth category to the four groups of "translations" from Sanskrit as described by Carl Ernst (2003: 174): the "scientific" works of Sultanate era, the "historical" endeavors of Akbar's court, the philosophical-comparative explorations from the time of Dārā Shikōh, and the early British colonial "informative" texts. We can provisionally identify this tentative "fifth category," indeed, in the more or less devotional (especially but not only

\footnotetext{
${ }^{1}$ For a survey on the shifting representation of the historical-poetical persona of Mīrzā Qatīl and his Hindu background in Indo-Persian tazkira literature, with special attention to the semiotics of his conversion, see Pellò 2012: 161-68 and 2016.

2 In a wider multilingual perspective, the multiple intersections at the level of poetic practices involved in similar processes (from, to, or within the Persianate space) have been explored in studies such as Busch (2011: 130-65) and Orsini (2014). Some relevant textual specimens more directly related to the IndoPersian sphere, primarily from Indo-Persian tazkiras, have been discussed by Pellò 2014: 30-42.
} 
Krṣnaite) works by munshīs identifying themselves (and identified in tazkira literature) as hind $\bar{u}$ and creatively applying to their textual identities the traditional Persian set of lexical tropes—such as butparast, șanamparast, and aṣnāmī—used to identify the "idolater." 3 As pointed out elsewhere (Pellò 2014), but I shall elaborate further here, studying this textual world means not only exploring how (a certain amount of) Vaiṣnava devotionality is projected onto the preexistent Persian poetic palimpsests, but also, and perhaps more importantly, measuring to what extent the poetical codes and protocols themselves are capable of moulding and widening their set of extra- and intra-textual references to accommodate such devotionality. In general, this paper also hopes to offer some useful insights into how to better articulate a series of questions revolving around the sociotextual (to use Sheldon Pollock's formulation) contours and refractions of the poetic self in a late Persianate environment. In such a context, the monumental Persian rewriting of the Bhaggavata Purāna (and especially of its tenth skandha) by one of the disciples of Mīrzā 'Abd al-Qādir Bīdil (1644-1720)—Amānat Rāy_seems particularly representative and promising, considering both the relevance of the poetic silsila Amānat appears to belong to and the fortune of his work in nineteenth-century printed editions. Indeed "Reading the Bhāgavata Purāna in Bīdil's Poetic Circle" would have been an appropriate alternative title for this essay; as we shall see, while textualizing Kṛ̣ṇa in his Persian Bhāgavata Purāna, Amānat is also responding to the stylistic and philosophical premises of his master's works, from his dīwān to his mașnawīs to his autobiography.

\section{The Textual Biography of Amānat Rāy}

The biographical data on Amānat Rāy appearing in tazkkira literature are relatively scanty. There is no entry devoted to him in the main source for Bīdil's maktab, the Safina-yi Khwushgū by Bindrāban Dās Khwushgū, nor in the tazkira gul-i ra'nā by Lachhmī Narāyan Shafīq, whose second volume is declaredly devoted to Hindu poets of Persian. ${ }^{4}$ While the reasons for this exclusion are not clear to me, short biographical sketches and a few verses of his do appear in other sources. The most important among these, and apparently the oldest one as well, is the Tazkira-yi Husayn̄̄, completed in Delhi by Mīr Husayndūst Husayn̄̄ in 1750 while Amānat was still alive:

The poet who embellishes the expressions, Amānat Ray, belongs to the Khatrīs of Lalpūr and is one of those people who were favored by the company of Mīrzā 'Abdul Qādir Bīdil. For a certain period he was the chief

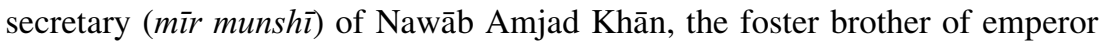

\footnotetext{
${ }^{3}$ For details regarding the use of the term hind $\bar{u}$ in premodern and early modern Persian literature, see Pellò 2012, 2014, and 2015. On the relevant complementarity of ethnography and trope in Mughal textuality, see also Sharma 2012.

${ }^{4}$ Some scanty biographical and bibliographical information on Amānat can be found in 'Abd Allāh (1992: 203-4), Baqir (2011), Anūsha (2001, 1: 260). As we shall see later in this paper, Amānat himself provides the reader with some significant autobiographical information in his own poetic works.
} 
Muḥammad Shāh. He once related this incident: "One night, I was walking near some ruins, thinking about writing a dīwān of verses, when suddenly, in the darkness, I saw a madman in high spirits dancing hand in hand, though respectfully, with my master. In the height of ecstasy, my master looked at me and said: 'Go, and a whole sea of pearls and rubies will for certain burst from the spring of the particles of dust!' And so I went, and I succeeded in completing my dīwān in a very short time." He translated the whole Srī Bhāgavat [Purāna], the Nāyikabhed, and other similar works from Hindi to Persian poetry (1875: 48-49).

Together with the personal relationship with his master Bīdil, the other main trait of the poetic personality of Amānat-that is, his interest in the Persian rendering of Indic works - as already been clearly stated by Husayndūst Husayn̄̄, who also pointed out his provincial Khatrī provenance and the courtly environment where he lived in Delhi. Just over fifty years later, in 1804, Bhagvān Dās Hindī, writing in Lucknow, adds some more information in his Safina-yi Hindī:

He was the munshī of Nawāb Amjad Khān. After the latter's death he was protected by Rahīm al-Nisā' begam, the Nawāb's sister also known as Kōka Șāhib, who used to pass him a monthly salary. In poetry he is a disciple of Mīrzā Bīdil. He has left a huge dīwān and versified long Hindi books (kutub-i mabsūtt-i hindī) such as the Bhāgavat and the Rāmāyan... (1958: 21-22).

The figure of Amānat is characterized, again, by his Persian poetic renderings of Sanskrit classics such as the Bhāgavata Purāna and the Rāmāyaṇa, to be added to the Nāyikabheda which is mentioned, as we have seen, in the Tazkira-yi Husaynī. This trend will continue in much later texts. Debī Prashād "Shād" mentions Amānat Rāy in his Tazkira-yi āṣār al-shu'arā-yi hunūd, a little-known collection of biographical notes and short verse anthologies of 656 Hindu poets writing in Urdu (and Persian as well) up to the second half of the nineteenth century:

Amānat: the takhalluṣ of Rāy Amānat Rāy, who used to live in Dihlī’s Darībā neighborhood. No details about his life are known. He must be the same Amānat Rāy who composed the versified translations of the Rāmāyan and the Bhāgavat (Debī Prashād 1885: 7).

Debī Prasād, who quotes only one Urdu line attributed to Amānat, basically identifies the author with the Persian versified translations of the Rāmāyana and the Bhāgavata Purạna; other biographical sources deal with Amānat as well, without however adding too much. ${ }^{5}$ As a matter of fact, by the time Debī Prashād is writing, Amānat's two main poetic enterprises, the Rāmāyan mentioned by Bhagvān Dās and Debi Prashād and the Bhāgavat mentioned by all his biographers, had already been circulating in printed editions, ${ }^{6}$ published by Naval Kishor in Kānpur and

\footnotetext{
${ }^{5}$ For instance, the Muntakhab al-lațā' if by Rahm 'Alī Khān Īmān (2007: 136), the Bāgh-i ma 'ānī by Naqsh 'Alī (1992: 28), and the Șubhh-i gulshan by Muhammad 'Alī Ḥasan Khān Salīm (1878: 37). These three texts indicate Amānat Rām instead of Amānat Rāy.

${ }^{6}$ The copy of the Srì Bhägavat 1-9 at the British Library, for instance, bears the stamp of the North-West Frontier Province.
} 
Lucknow from the late 1860 s onwards. ${ }^{7}$ Remarkably enough, as far as the subsequent identification of his figure with the main subjects of his literary production is concerned, Amānat is described, on the cover page of the printed edition of the eleventh iskand (skandha) of the Srì Bhāgavat (1868), as "Expert of the Vedas, learned in the śāstras and bhakta" (dānā-yi bēd wa shāstragyān̄ wa bhagat). Further stressing the "specialized" character of his poetic production and confirming Husayndūst Husayn̄̄’s and Bhagvān Dās's statements about Amānat composing other Persian remakes of "Hindi" works beyond the Bhāgavat, the Rāmāyan, and the Mașnawī-yi nāyak, a Bhagatmāl (that is, Bhaktamāl, a collection of hagiographies of Indian saints, in mașnawī form) also exists, of which two manuscripts (one incomplete) are preserved in Pakistani libraries (Munzawī 1985: 2140). As the nineteenth-century editor of Amānat's Persian Rāmāyan clearly states in his introduction to the book, his Bhāgavat, contrarily to the Rāmāyan "which since its composition has been difficult to find until now" (ki az zamān-i tașnîf tā indam nihāyat nāyāb būda-ast), is by far the most "famous and renowned" (mashhür wa ma'rūf) of his literary works (Amānat 1872: Cover). Along with the Rāmāyan, with roughly forty thousand lines, this text is also the most consistent of Amānat's poetic efforts, confirming Sayyid 'Abd Allāh's judgment of our author as a "very prolific writer" (1992: 203).

The core of Amānat's Bhāgavat is not surprisingly the tenth skandha, which was the first part of the Puraṇa reworked by the Khatrī student of Mīrzā Bīdil and, according to all available evidence, was initially conceived as an independent work. As a matter of fact, the book bears the title Jilwa-yi za āt ("The Epiphany of the Essence"), which is also the chronogram of the date of its completion (AH 1145, that is, 1732-33), a key to understanding the Persian poetic textualization of the notion of the avatāra and a direct quotation from a perceived model of Șūfĩ poetics such as Hāfiż's dīwān (Amānat manuscript, folio 17b). ${ }^{8}$ The rendering of the other skandhas was achieved by Amānat during the successive decades of the eighteenth century (the final date of completion of the rest of the Bhaggavat is indicated as the year 1807 of the Vikram era, corresponding to 1751; Amānat Nd: 695). Interestingly enough, Hermann Ethé describes the manuscript copy of the Jilwa-yi żāt in the India Office collection in London as "A very large mathnawi on the adventures of Krishṇa, interspersed with many ghazals and rubâ'îs, and founded on Sanskrit sources, by a poet with the takhallus Amânat" (1903: 918n1696). Probably on this imprecise description, the Jilwa-yi żăt was erroneously described as an "original composition" in some secondary sources that never name the Bhāgavata Purāna in

\footnotetext{
7 Compare Amānat 1868, 1870, 1872.

8 Jilwa-yi zāat is found in one of Hāfiẓ's most famous ghazals: ba 'd az īn rūy-i man u āyina-yi vașf-i jamāl / ki dar ānjā khabar az jilwa-yi żāt-am dādand (Heretofore I shall turn to the beauty-describing mirror / because there they made me aware of the epiphany of the essence) (Hāfiz 1983-84: 372). The notion of tajallī-yi zāt (tajallī and jilwa being virtually synonymous), "the epiphany of the essence," has an important place in the conceptual universe of classical Persian Șūfī poetry and is explained in the glossary by Sayyid Ja'far Sajjādī as the "unveiling of the sun of the truth of supreme Truth (haquiqat-i haqqq-i ta 'ālā)" (1991: 223).
} 
relation to this book. ${ }^{9}$ The text is actually an all-inclusive rendering of the entire tenth book of the Bhāgavata Purāna, a favorite among translators ${ }^{10}$ and also, as already noted (Pellò 2014), a specific topos within Bīdil's maktab in Delhi. A mașnawi in the hazaj-i musaddas-i mahzzūf meter, ${ }^{11}$ a favorite in Persian romance writing since Fakhr al-Dīn As'ad Gurgān̄̄'s Wīs $u$ Rāmīn (eleventh century) and Nizāmī’s Khusraw u Shīrin (twelfth century), the Jilwa-yi zāt is an extensive work interspersed with a great number of ghazals and rubā'is, consisting of about seventeen thousand bayts collectively. The work is subdivided, both in the lithographed Naval Kishor edition and in the India Office manuscript, into ninety chapters corresponding quite precisely, in terms of narrative contents, to the ninety adhyāyas of the Bhāgavata Purāna. These are preceded, in the printed edition, by a brief autobiographical note (mājarā-yi sarguzasht-i mușannif-i srī bhāgavat) (Amānat 1870: 1-5), a description of the causes leading to the composition of the book (sabab-i nazm-i kitāb) (5-9), a long introduction (shurū'-i kitāb-i mustatāab-i srī Bhāgavat) (10-26), and several invocations (munājāt) (26-27). The order of these introductory sections is slightly different in the India Office manuscript (copied in 1772), where the introduction (folios 1-11b) and the invocations (11b12b) precede the autobiographical note (13a-15a) and the occasion for the manuscript's composition (15a-18a). The descriptive titles of the narrative sections corresponding to the adhyāyas are already present in the manuscript as well (in red ink), with some minor discrepancies in the printed text. As mentioned above, the correspondence with the traditional subdivision of the Bhāgavata Purāna is generally respected, and, with some exceptions (chapters 1 to 4 in the India Office manucript and 1 to 3 in the Naval Kishor edition cover adhyāya 10.1 and 10.2), each chapter corresponds to one adhyāya. A preliminary comparison of the Jilwa-yi zāt with the other skandhas of the Bhāgavata Purāna rendered in Persian by Amānat reveals that the special attention given by Amānat to the recreation of the most beloved book of the Purāna is already apparent from a simple quantitative analysis: with around seventeen thousand lines, the ratio between the Jilwa-yi za $\bar{a} t$ and the Sanskrit tenth skandha of the Bhāgavata Purāna is an average of about four bayts for every śloka; whereas in the case of Srī Bhāgavat 1-9 (fourteen thousand lines), the average ratio is less than two bayts per śloka. Within this generally intensified focus, the Rāsapañcādhyāy $\bar{\imath}$ receives a particularly attentive treatment; in the India Office manuscript, for instance, the Persian version of adhyāya 10.30 alone takes up almost seventeen pages (folios 104a, verse 12 to $112 \mathrm{~b}$, verse 4), corresponding to about two hundred eighty bayts, compared to the forty-four ślokas of the Sanskrit text (more than six bayts per śloka). This is not only very much in line with the fortune of the pañ $\bar{a} d h y \bar{a} y \bar{\imath}$ in the vernacular literary space, which must have been

\footnotetext{
9 Compare Baqir 2011 and Mujtabai 1978: 75. Mujtabai mistakenly identifies this work as the Persian Bhagavad Gìtā by another disciple of Bīdil, Lāla Hukm Chand Nudrat.

${ }^{10}$ The Bhāgavata Purāna (especially the tenth book) had a remarkable success in Persian, both in prose and in poetry: incomplete (and not always precise) lists can be found for instance in Mujtabai (1978: 76-78) and Sharma (1982: 30-31). In more recent scholarship, a reconsideration of the Mughal translation movement is Truschke (2016). Keshavmurthy's (2018) study of Masīh's seventeenth-century version of the Rāmāyana another favorite with Indo-Persian writers-makes a good parallel reading for this paper.
}

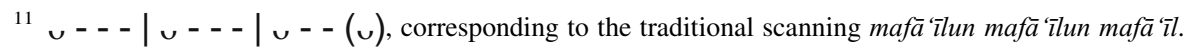


among the immediate sources for Amānat's work, but also-and more interestingly for our purposes here-with the interest of the Braj mandal as the locus for the erotic pleasures of Kṛ̣na and for Krṣna himself as a typological ma shüq in IndoPersian poetic maktabs. As a matter of fact, the Persian chapters on the rāsalīlā offer a privileged observation point to initiate a discourse on the pragmatics of those comparative poetics evoked by several eighteenth-century critics. Just to name a couple of relevant cases: the pages of Lachhmī Narāyan Shafīq (not by chance a disciple of the eighteenth-century "comparativist" Āzād Bilgrāmī) on Krṣna as the eternal beloved, where the lyrical language of Persian ghazal works like a "dubbing"12 of the Indic imagery that is the object of his descriptions (Pellò 2014: 40); on the side of reception, the instrumentality of this kind of textual asset in providing a wealth of homogeneous literary material — forming a continuum with the transregional Eurasian dimension of the world of Persianate literature-for later observers and popularizers such as Mīrzā Qatīl (who explicitly refers to Kṛ̣ṇa when insisting that "the people of India," ahl-i hind, tend to describe love in poetry as the love of a woman for a $\operatorname{man}^{13}$ ) or, for that matter, the British with their puritan approaches. ${ }^{14}$

\section{Envisioning the Pañcādhyāȳ in Persian}

Let us consider, as a preliminary sampling, Amānat's remake of Bhāgavata Purāṇa 10.29 (Amānat manuscript, folios 100a-104a). ${ }^{15}$ The title chosen by the author is "The raising of the head towards madness of a multitude of women in the dark night / in search of a meeting with that moon without faults" (sar kashīdan ba junūn-i khayl-i zanān dar shab-i tār / dar talabkārī-yi dīdār-i mah-i bìnuqșān). The expressions,

\footnotetext{
${ }^{12}$ Here I attempt to conceptualize - by recurring to the familiar cinematographic metaphor of the dubbing of a movie in a foreign language - the tendency to use Persianate correspondents to summon simultaneously Indic poetic images; in Lachhmī Narāyan Shafĩq's tazkira, for instance, a verse where the canonical couple of lovers Laylā and Majnūn are used to "visualize" the preceding discussion on Kṛ̣na and the gopis (see Pellò 2014).

${ }^{13}$ Qatīl (1875: 7) is comparing three different practices of describing love in poetry: whereas the Indians would favor a woman-to-man perspective, he says, the Arabs would do exactly the contrary while the Persians ('ajam) would talk about it as a homoerotic experience.

${ }^{14}$ In the preface to the second volume of his History of Hindostan, Thomas Maurice introduces Nathaniel Brassey Halhed's English abridgement (from a Persian original) of the daśama skandha, included in the book, as follows: "I have not presumed to alter it farther than to blot out some parts which, however agreeable to a highly-seasoned Oriental palate, appeared to me to glow with colours and images not sufficiently chaste for an European eye. I should have erased more, but it was necessary that the reader should judge for himself concerning this motley character, which has been so impiously paralleled with that of the Christian Messiah....The reader must see Creeshna as he is, to judge of him properly; he must contemplate him with all the puerility and licentiousness, as well as with all the virtue and dignity, attached to his Avatar. I never intended to do the work of the adversary, by making Creeshna a perfect model of an incarnate Deity" (1798: viii-ix; emphasis in original). The figure of Kṛ̦na is here even used with an anti-French purpose: with a sarcastic tone, Maurice writes that suggesting that "the history and miracles of Christ were borrowed from those of the Indian Creeshna" would have the "laudable purpose of plunging Christian Europe into all the horrors of atheistical France" (vi).

${ }^{15}$ Due to its relatively early date, its interesting transmission (see the last section of this paper), and the fact that it is integral, I prefer here to base the textual analysis of the Jilwa-yi zzatt solely on the India Office manuscript.
} 
metaphors, and semantic paradigms (the defiant madness of the lover / Majnūn, the longing for the "meeting" with the beloved) selected by Amānat to introduce the celebration of the passionate love of the gopis for Krṣna, all deeply immersed into the broad lexical and metaphorical hypertext of Șūfī poetics, ${ }^{16}$ are, as a whole, reminiscent of the well-known episode of the Egyptian women losing their minds at the appearance of Joseph's beauty in 'Abd al-Raḥmān Jāmī's famous maṣnawī, Yūsuf $u$ Zulaykhā (fifteenth century). ${ }^{17}$ Furthermore, if we look closer, at least three expressions are direct quotations from powerfully normative canonical works of preMughal Persian poetry, all part of the linguistic education of a munshi $:^{18}$ (i) khayl-i zanān "multitude of women" comes from the didactical Būstān of Sa 'dī (thirteenth century), ${ }^{19}$ (ii) shab-i tār "dark night" clearly echoes the shab-i tārīk evoking the asperities of the path of the seeker, which introduces the fourth line of Hāfiz's first ghazal in the Dīwān (1983-84: 18), and (iii) mah-i binuqșān "moon without faults" is taken directly from Mawlawī Rūmī's masterpiece of lyrical 'irfān, the Dīwān-i Shams (thirteenth century), precisely from a stanzaic poem where the dominant theme is a dance with a beautiful Christian (tarsā) youth (Rūmī 1999: 1196-7). The significance of such intertextual ties is even more notable if we look at the immediate literary surroundings of the Jilwa-yi żāt. The reference to the "madness" (junūn) of the gopis as an exemplary figure of love is, as a matter of fact, the key rhetorical feature of the passage devoted to the description of Mathurā by Amānat's master, Mīrzā Bīdil, in his own autobiography, where the prose evocation of the "tears of the gopīs" and Krṣna's bämsuri is followed by the "subtitles" of three ghazal lines revolving around "Majnūn's valley" (wādī-yi majnūn). Similarly, a bayt dealing with the "desert plains of Majnūn" (ṣahrāa-yi majnūn) by Āzād Bilgrāmī is used by Lachhmī Narāyan Shafīq to comment upon his explicative description of the gopīs' love for Krṣna in the Indian "love poems" (references and translations in Pellò 2014). Amānat then dubs the first two ślokas and half of the twenty-ninth adhyaya, depicting the autumnal nights in Vrindāban, as follows:

\section{shab-ī chūn zulf-i khübān mațla'-i nūr \\ tajallībakhsh-i sham'-i rawshan-i țūr}

sawād-ash sarkhaț-i lawh-i tamannā

bayā̇̇-ash nuskha-yi ḥusn-i dilārā

\footnotetext{
16 Generally speaking, the Akbarian anagogical systematization of Indian commentaries on major Persian Suficate works such as Rūmī’s Maṣnawī or Hāfiẓ's Dīwān-I am thinking here, for instance, of the ready-made frames of the reference provided in Khatmī Lāhurī’s Maraj al-bahrayn (1628)—should be considered a probable source for Amānat's textual adaptations (as well as those of several other eighteenth-century Hindu Persian poets).

17 The episode (Jāmī 1998: 78) is directly based on Qurān 12:30-32.

18 An interesting catalogue of the Persian texts to be studied by a seventeenth-century Hindu secretary writing in Persian can be found in the letter written by Chandar Bhān Barahman to his son Tej Bhān (the letter is published in 'Abd Allāh 1992: 268-70 and has been translated into English by Alam and Subrahmanyam 2004: 62-63).

19 The expression appears in the first chapter of the didactic poem-one of the pillars of the linguistic education of any premodern and early modern Persianate intellectual from Bosnia to Ningxia-by Sa 'dī (consult Sa'dī 1954: 315).
} 
zamīn az jilwa-yi sarshār-i mahtāb

tamawwuj dāsht hamchūn āb-i sìmāb

ba saṭh-i āsmān anbūh-i akhtar

numāyān dar țabaq chūn musht-i gawhar

falak az lam 'a-yi māh-i jahāngīr

labālab būd hamchūn kāsa-yi shīr (Amānat manuscript, folio 100a)

A night resembling the curls of the beauties, an opening verse of light, offering the epiphany of the bright candle of Mount Sinai.

Its blackness was the leading line of the blackboard of desire its whiteness the manuscript of the heart-adorning beauty.

With the inebriated epiphany of moonlight, the earth made a wave-like movement, resembling quicksilver.

On the surface of the sky, a myriad of stars were showing themselves on a plate like a handful of pearls.

The sky, with the flashes of the world-conquering moon was overflowing like a bowl full of milk.

The imagery chosen by Amānat to represent the bliss of the nocturnal environment, while in general substituting the reddish tones of the Sanskrit (aruna, kunkuma) ${ }^{20}$ with the Persian ultra-classical black and white contrast (shab "night" / nür "light," zulf-i khübān "dark curls of the beauties" / sham 'i rawshan "bright candle," sawād "blackness" / bayā̇ "whiteness"), contains some notable specific references as well. The Biblical and Qur'ānic bush of fire of Mount Sinai (Ṭūr), representing the epiphany of God to Moses, is not only a centuries-old Persian poetic metaphor, in perfect harmony with the repeated mentions of the notion of manifestation so central to Amānat's work (tajallībakhsh and the very jilwa), but also a clear allusion to the work of the most representative masters of Mughal-Safavid times. As a matter of fact, the very expression sham ' $i$ ț $\bar{u} r$ appears to be relatively popular in the authoritative ghazals by Șā'ib-i Tabrīzì and occurs as well in other great authors of the seventeenth century like 'Urfī Shīrāzī, Waḥshī Bāfqīi, and, most notably for our purposes here, Mīrzā Bīdil, ${ }^{21}$ who uses the image of Mount Sinai as a place for the

\footnotetext{
${ }^{20}$ A detailed and articulated comparison of the aesthetic interactions between the Sanskrit Bhägavata Purāna and the vernacular adaptations most likely available to Amānat, on the one hand, and the Persian text, on the one hand, is of course highly desirable. While deferring such an endeavor to a future studythe textual world of Amānat's readings, with the partial exclusion of the Persian ambit, still needs to be reconstructed-here I will be content with making general reference to the Sanskrit text as examples of a fruitful way to move forward, of course to be soon enlarged to the vernacular contexts.

21 The image occurs several times in Șā'ib-i Tabrīzì̀'s Dīwān (see, for example, 1985-95, 1: 146, 371; 2: 671, 908; 5: 2690). Compare also Waḥshī-yi Bāfqī (2001: 470) and especially Amānat's master Bīdil (1997, 2: 213). While, for the purposes of this paper, I strongly prefer a reading of Amānat's work as seen through the specific stylistic lens of the masters of the Mughal-Safavid period, and especially of his ustād Bīdil, it should of course not be forgotten that all the tropes mentioned in this paper have a long history in Persian poetry, often going back to the Samanid and Ghaznavid times and even to the Arabic poetry of the Abbasid courts. For a general introduction to the conventional imagery of Persian poetry, see Zipoli 2009.
} 
appearance of knowledge even as the icastic title of one of his mașnawīs, the Tū $r-i$ ma'rifat. To proceed with a tentative comparison with the Indic aesthetics just mentioned, it is worth noting that the dense intertextual figure of the fire of Mount Sinai also represents a powerful change of dress for the equally paradigmatic image of divine epiphany represented by the similitude of the splendor of the face of Lakșmī (Sanskrit ram) in the original textual environment. In addition, the equally iconic images related to milk dominating śloka 5 (duhantyah; doham; payah) in the Sanskrit text are anticipated and condensed (and never touched again) in Persian by the reference to the sky "overflowing like a bowl of milk" in line 5. With such a rich and articulate rhetorical play of transformations, relocations, quotations (tażinn), and replies (istiqbāl), one should not forget however the creative role of all the familiar Persian images in effectively evoking, on the part of the reader used to the above-described comparative practices, the black yet luminous beauty of Kṛ̣na himself, who actually appears in the following lines:

ba taklīf-i bahār-i 'aysh hamdast

srī krishn zi jām-i husn-i khwud mast

șabāāsā ba sūy-i ban rawān shud

bahār imrūz har barg-i khazān shud

ba istiqbāl-i $\bar{u}$ taraf-i chamanhā

bar āmad būy-i gul az pīrahanhā

ba gulshan bā hujūm-i shawq har dam

shud az bahr-i sujüd-ash shäkh-i gul kham

gul ānjā chūn 'arūs-i nawrasìda

libās-i surkh-rā dar bar kashīda (Amānat manuscript, folio 100b)

Hand in hand with all the fanfare of a spring of pleasure

Srī Krṣna, intoxicated by the cup of his own beauty,

like a breeze began moving towards Ban:

today every autumn leaf has become a spring.

In order to welcome him, towards the meadows,

from the shirts soared a perfume of rose.

In the rose garden, with the assault of passion every instant the branch of the rose has bent to bow down to him.

There the rose, as a young bride wore a red dress on her body.

The "divine power" (yogamāyā) that Kṛ̣na resorts to while "turning his thoughts towards the enjoyment of love" (rantum manaś cakre) in śloka 29.1 is overwritten, in Amānat's Persian remake, by the cardinal monistic-narcissistic notion, in Suficate literature, of the supreme identity of love, lover, and beloved (ishq, 'āshiq, and $m a$ 'sh $\bar{u} q$ ), here inflected through the image of Kṛ̣na "intoxicated by the cup (jām) of his own beauty (husn)." Other than the several possible classical antecedents 
related to the interconnected ideas of the reflective powers of the cup-mirror-heart and of God as both the creator and the lover of the reflection of his own beauty, it is worth pointing out that a direct source in conceptual poetics is to be found in the work of Amānat's master, for instance in Bīdil's cosmogonical mașnawī, Muḥ̂țt-i a 'zam, where the metaphor of the "passing around" of the cosmic Wine Cup by the eternal Cupbearer has a constitutive role. ${ }^{22}$ Beyond the mașnawi environment, a strikingly precise parallel, in terms of imagery, comes from the Dīwān of Mīrzā Bīdil (1997, 2: 516):

mastī-yi ḥusn u junūn-i 'ishq az jām-i man-ast

dar gulistān rang-am $u$ dar 'andalībān nāla-am.

The intoxication of beauty and the madness of love come from my cup:

I am the color in the rose garden, I am the lament of the nightingales.

The entire textual landscape of the opening of Amānat's pañcādhyāȳ is already present in Bīdil's line, marked by precise lexical parallels: the "intoxication" (mastī), the "cup" (jām), the "rose garden" (gulistān), the "color" (rang), the implied junūn "madness" that we have dealt with above, and even the "lament" (of the gopis-nightingales) that appears a few lines later. In such a deeply intertextual milieu, the self-reflective epiphany of the beloved Krṣna is set in the prototypical Persian lyrical landscape of the garden into which the forest of Ban, colored by the gentle rays of the moon (vanam ca tat komalagobhi rañjitam), is transformed. The autumnal luxuriance of the North Indian natural scenery is maintained, in Persian, through the repeated exploitation of the rhetorical device of the husn-i ta ' $l \bar{l} l,{ }^{23}$ which again, at least in the case of the personified abstraction of the "assault of passion" (hujūm-i shawq), includes another precise Bidilian echo as well as a general stylistic tribute to other masters of tāzagīy $\bar{l}^{24}$ Thus, thanks to the appearance of Krṣna, "every autumn leaf" can "become a spring." Autumn, which in the Persian tradition is, in sharp contrast with Sanskritic aesthetics, the season of dryness and decay, can be magically turned into its own opposite, without distorting in the slightest the Indic original timing of the year and while keeping the rāsalīla event in its proper South Asian season. In other words, exploiting the possibilities provided by rhetorical devices, it is the Persian fall (khazān) that is transformed into a springthus properly corresponding to the Indic autumn (śärada) of the textual settingand not the reverse. The above-mentioned translatability of Kṛ̣na with Joseph / Yūsuf is cleverly harnessed by the reference to the "perfume of rose" (büy-i gul) soaring from the "shirts" (pīrahanhā); Amānat is alluding here to the famed episode of the "perfume of Yūsuf's shirt" (būy-i pīrāhan-i yūsuf) substituting and

\footnotetext{
22 On the Muhitt-i a'zam, see Kovacs 2013.

23 The husn-i ta 'lìl, literally "beauty of rationale" and generally translated as "fantastic etiology," is among the most widely employed figures of the so-called 'ilm-i badi', or "science of rhetorical embellishment." Chalisova (2012) properly defines this figure, already described in the earliest Persian treatises on 'ilm-i badī" (eleventh century), as a "a conjunction of fantastic images within a syllogism" that "creates additional levels of opposition in the line, rationally 'proving' the possibility of the impossible and thus presenting lies disguised as truth."

24 A number of textual parallels can be found for instance in Bīdil (1997, 1: 580; 2: 36, 362), but also in Șā'ib-i Tabrīzī (1985-95, 3: 1538; 4: 1967).
} 
anticipating Ya'qūb's vision of his most beloved long-lost son (based on the "most beautiful story" of Qurān 12, and very popular, for instance, with Rūmī's Maṣnawīyi ma 'naw $\vec{\imath}) .{ }^{25}$ With this reconstructed, recontextualized, and "told anew" (that is, in a tāzag $\bar{u} y \bar{\imath}$ voice) background of heterotopic spring colors and perfumes, the voice of Kṛ̣ṇa's bāmsurī is finally heard:

dar ānjā az hawāy-i naghma-yi nāz

ba nay la 'l-i lab-i $\bar{u}$ shud hamāwāz

zi bas az fayż-i la 'l-ash bahrawar shud

nay-i khushk az halāwat nayshakar shud

chunān nay shu 'la zad dar kharman-i jān

ki dil-rā sūkhtan gardīd āsān

ma-rā z-īn chūb-i khushk-i lālasāmān

ba dast-i hayrat uftād-ast dāmān

ki bā labhā-yi $\bar{u}$ hamāshyān shud

halāwathā-yi 'ālam-rā żamān shud

zi āwāz-ash chunān zad bīkhwud-i bīhūsh

ki shud har kas zi yād-i khwud farāmūsh

chi akhgar dar bar-i khwud dārad in nay

ki labrīz-i sharar shud har rag-i way

chunān dar 'ishq sur'atdastgāh-ast

ki az dil tā ba ū yakwajh rāh-ast

zamīn khāk-ì ba sar az shawq-i nay shud

falak dar gardish az āwāz-i way shud

magar ārad zi sūy-i yār payghām

ki nay az dil kunad tārāj-i ārām (Amānat manuscript, folio 100b)

There, with the passionate air of a coquettish lament

the ruby of his lips became harmonious with the flute.

And the dry flute was so favored by the grace

of his ruby that, with that sweetness, it became a sugarcane.

The flute threw such a spark in the harvest of life

that it became easy, for the heart, to catch fire.

Because of this tulip-like dry wooden stick

the lap of my dress fell in the hands of bewilderment.

Whoever became intimate with his lips,

became the guarantee of the sweetness of the world.

\footnotetext{
25 The scent of Yūsuf's shirt is the subject of a celebrated twenty-five line paragraph in the third daftar of Mawlawī's poem (Rūmī 1996: 431).
} 
What firebrands does this flute bring with itself, that every single fiber is brimful with sparks.

It is so quick moving in love that from the heart to it is only a step.

The earth felt desperate because of the passion of that flute the sky began rotating because of its sound.

Perhaps it also brings a message from the beloved, because the flute plunders tranquility in the heart....

The bāimsurī briefly mentioned by Mìrzā Bīdil while speaking of Mathurā in his Chahār 'unșur (see Pellò 2014: 35-36), and not even named in the corresponding passage of the Sanskrit text, is the object here of a poetic commentary composed of no fewer than nine whole couplets. If, in Bīdil's model work, Kṛ̣na’’s flute is mirrored by the narrow alleys of the city and echoed by the wind passing through them "throwing sparks which make the dust dance (shu 'laāhang-i ghubārangīz)" (Bīdil 1965-66: 148), in Amānat's Jilwa-yi zāt an entire set of canonical imagery for the flute is conjured up to give it a dynamic description. In this case, the representational weight of the traditional iconography of Kṛṣna with the flute encounters the possibility of being naturalized in Persian. This is achieved by drawing on a rich and apt metaphorical lexicon; the theme of the flute makes up for a substantial number of lines in most authors of ghazal and Suficate masnawi, beginning with the ubiquitous "song of the cane" that opens Rumī's Masnawī-yi ma 'nawī, with all its figurative connections to the central topos of the lament ( $n \bar{a} l a$ ) for separation (hijrat). By unfolding and amplifying a familiar literary image to textualize the iconic figure of Krṣna as a flute player, Amānat is adopting, as a matter of fact, the same strategy that allows eighteenthcentury tazkira writers to reuse a comfortable referential repertoire to include "new" literary actors (such as the hind $\bar{u}$ Khatrī and Kāyastha writers), so to say, in the collective majlis of Persian literature. In this case, he is exploiting the rich and centuries-old set of imagery and metaphors relating to the world of "unbelief" from the $z u n n \bar{a}{ }^{26}$ to the fire-temple (Pellò 2012: 183-98). It is thus not only (or not so much) Krṣna who enters the Persian poetic codes, but, more aptly and subtly, the codes themselves that see their set of possible extra- and inter-textual referents enlarged to paradigmatically include Krṣna. The nay, while remaining a nay for all Persian poetic matters and purposes, at the same time calls upon the tune-setting opening of Rūmī's 'irfān̄̄ masterwork, 'Abd-al Raḥmān Jāmī’s influential Naqshbandi reading of it, ${ }^{27}$ as well as Kṛ̣ṇa's Sanskritic and "bhakta" bāmsurī, in a polysemic dimension and with no real break. The gopis complete this picture:

ba gūsh-i güpiyān tā shud șad̄̄-y-ash

zi khwud chūn nāla raftand az barāy-ash

\footnotetext{
${ }^{26}$ The zunnār-originally the belt of the Byzantines and a very common lexical item in poetry to characterize various kinds of "infidels"- is often used in the Indo-Persian literary world as the referent to "translate" the Brāhmanical thread.

27 I refer here to the famous commentary on the first two verses of Rūmī's Mașnawīyi ma 'nawi known as Risāla-yi nā'iya or Naynāma (see, for instance, Ridgeon 2012).
} 
hama chūn șūrat-i dīwār mānda

ki dil az dast $u$ dast az kār mānda

zi āwāz-ash yak-ī barjast az khwāb

rawān dar rāh-i $\bar{u}$ chūn nāla bìtāb

yak-ī bar khāk bīhūsh-i $\bar{u}$ futāda

'inān-i dil chu ashk az dast dāda

yak-ī à 'inasān maḥw-i khayāl-ash

yak-ī parwāna-yi sham'-i jamāl-ash

yak-ī nām-i kanayh $\bar{a}^{28}$ bar zabān dāsht

yak-ī az bīkhwudī bā khwud nishān dāsht

yak-ī gum karda rāh-i khānimān-rā

yak-ī sar karda az shawq-ash faghān-rā (Amānat manuscript, folios 100b-101a).

When its voice reached the ears of the gopis,

as a lament, they left themselves for him.

All of them were stunned like images on a wall:

the heart had stopped working, because of him.

Because of his voice, one rose from sleep

and, like a lament, restless, began walking towards him.

Another fell on the earth deprived of her senses,

having left the reins of her heart like a tear.

One, like a mirror, was nothing other than the imagination of him, another was the butterfly of the candle of his beauty.

One had on her lips the name of Kanhayā

One, having lost herself, was inquiring after herself.

One had lost the way to her household

one, full of passion, had begun to shout....

The variety of the reactions of the women of Vraj described in ślokas 5-11 is read under the poetic species of the "madness of love" junūn-i 'ishq, along the same lines described above. Thus, Amānat's gūpiyān are at the same time a reflection of the cowherdesses of Vrindāban abandoning their homes and their husbands for Kṛ̣ṇa and a multiplication of the Qurānic and classical Arabic-Persian literary figure of Zulaykhā losing her mind and her honor for Yūsuf. The poet, one is tempted to say, is describing a whole bed of reeds (nayistān) of plangent reed flutes (nay) longing in separation for the beloved, the dominant rasa of viraha being appropriately filtered through the above-mentioned topos of hijrat. As in the above-mentioned cases, precise references to the textual mirrors of literary contemporaneity can be found here as well. First of all, the whole section is closely reminiscent, beginning with the very peculiarities of verse construction (the repetition of $y a k-\bar{l} . . /$ "One..." at the

$\overline{28}$ The metathesis Kanayhā $<$ Kanhayā is due here to reasons of meter. 
beginning of each line), of the relatively long part (eighty-nine bayts) of the third chapter of Bīdil's mașnawī, Muhịt -i a 'zam, where a number of ecstatic reactions to the turning of the cosmic Wine Cup are described (Bīdil 1997, 3: 609-12). In more detail, the use of the widespread visual metaphor of the "images on the wall" (șurat$i$ dīwär) can be closely linked to the complex and articulate discourse on the conceptual semiotics of the portrait made by Bīdil in the Chahār 'unșur, where the very image of the wall-paintings is used to metaphorically reflect both on the creative activity of the Deus pictor and on the conditioned actuality of individual existence. ${ }^{29}$ The intimately related theme of the mirror (äyina) - a most representative key image of Bīdil's poetics (and, of course, of the whole Persian repertoire ${ }^{30}$ ) and its metaphorical substitutes (for example, the cup, jām, or the particles of dust, zarra)—is used to illustrate the reflective relationship between the gopis / lovers and the appearance of Kṛṣna / beloved. In the above-mentioned lines, the gopis are "nothing but the imagination" (maḥw-i khayāl) of Kṛ̣na, "like a mirror" (āyinasān), as, in the following line of Bīdil (where the same expression maḥw-i khayāl is used), where every man is nothing but a bewildered, only illusorily distinct and individualized reflection:

$\bar{a} y \bar{i} n a$ naqshband-i gul-i imtiyāz nīst

maḥw-i khayāl-i khāna-yi ḥayrānī-yi khwud-īm (Bīdil 1997, 2: 573)

The mirror is not the creator of images of the flower of distinction:

we are nothing but the imagination of the house of our bewilderment.

Such transitional Șūfī-Vedāntic tones, and the related imagery of cups, mirrors, and reflections, are maintained in the rendering of the subsequent dialogue between Parīkșit (parīchit) and Suka (sukhadev), where the doubt of King Parīkșit (how could the flow of the gunas of the gopis cease, if they saw Krṣna as a beloved and not as the Brahman?) helps us to focus on the inner aspects of suiratparastī, the "adoration of the forms." 31 The following three lines from the ten-bayt-long question of Parīkșit are a good summary:

zi la 'l-i yār shīrīnkām gashtand

tuhī az khwud ba rang-i jām gashtand...

hama ẓāhirparastān-i khațt $u$ khāl

hama āyinasān mushtāq-i timșāl

chisān dīdand husn-i bīnishān-rā

bidānistand asrār-i nihān-rā (Amānat manuscript, folio 101a)

\footnotetext{
29 This conceptually dense episode in the autobiography of Bîdil (1965-66: 281-86) - already highlighted and summarized in Abdul Ghani (1960: 57, 67-68)—has been recently analyzed by Keshavmurthy (2016) and also discussed by Pellò (2017b).

30 See Habīī̄i and Bābāȳ̄ 2013; Zipoli 1997, 2013.

31 As far as the challenging issue of the cult of the images is concerned, it is worth noting here that the little explored textual world of the eighteenth- and early nineteenth-century Persian writing munshi even includes a specific treatise on the subject, the Hujjat al-Hind, or the Proof of India (see Mujtabai 1978: 89).
} 
Their mouths became sweet thanks to the ruby lips of the Beloved:

like a cup, they became empty of themselves....

They were all worshipers of the external form of down and mole, like mirrors, they were all yearning for the simulacrum.

How could they see the beauty without signs?

How could they come to know that hidden secret?

Kṛṣna-Parikșit is suggesting in his (rhetorical) question-appears in the mirror of the gopis, who are "empty of themselves" like the convex emptiness of the cup, whose paradoxical essence corresponds to the empty space ready to receive the wine, evoked as well by the la 'l "ruby" of the Beloved's lips. Looking at the output of Amānat's master Bīdil (and to the works of several other tāzagū authorities), it is quite easy to link this reading of the gopis like blanks to be filled (the cup as well as, again, the empty mirror "yearning for the simulacrum") to a complex series of other images used to meditate on the functions of șurat / "form" as a precious index; from the naqsh-i pa "footprint" to the habāb "bubble" to which, for instance, Bīdil devotes an entire twenty-two-distychs detailed description in his masnawī, Țūr-i ma'rifat. I quote here two lines as an example of Bīdil's poetic-philosophical argumentation, to which we can be reasonably sure Amānat is responding:

zahī waż'i habāab-i bì sar u pā

ki hayrānī zi naqsh-i $\bar{u}$-st paydā....

sabukrūḥ̄ waqār-i imtiyāz-ash

tuhī az khwud shudan sāmān-i nāz-ash (Bīdil 1997, 3: 540)

Behold the state of the powerless bubble

from whose image bewilderment appears....

Having a light spirit is the honor of its distinction

becoming empty of itself is the equipment of its gracefulness

Just like the empty cup and the empty mirror of Amānat's line on the gopīs, Bīdil's bubble is instrumental in building a metaphorical play of paradoxes on the binary notion of emptiness and fullness, here allowing the logical-situational transformation (again, through the formal analogy of a round shape) of an essence-ofemptiness like the bubble into the gawhar / "pearl," the centuries-old Persian poetic image of essence par excellence. Suka's reply (which in the Persian text covers no less than twenty-two bayts) maintains the same tenor in terms of the imagery chosen to talk about the manifestation of Krṣna, who is read, to select just one example, through the image of the light of the sun being reflected by the endless multitude of mirrors represented by the particles of dust:

miṣl-i khwurshid harjā jilwagar shud

hujūm-i zarra har sū dar naẓar shud (Amānat manuscript, folio 101b)

Like the sun, he manifested himself in every place:

the assault of the particles of dust became visible in every direction. 
As in the previous cases, the weight of the experimentations of Amānat's masters and predecessors is easily recognizable. In this respect, Amānat's "solar" introduction of Krṣṇa seems to be replying to the following line by Șā'ib-i Tabrīzī, built on the very image of the "assault of particles" (hujūm-i zarra):

az nūr-i wah̆dat ānki dil-ash bahrawar shawad

kay az hujūm-i żarra parīshānnazarar shawad (1985-95, 4: 2051).

The person whose heart has had its part of the light of oneness

how can he be disoriented by the assault of the particles of dust?

Notably enough, Amānat's figure of the Kṛṣna-sun multiplied in the atoms shimmering in the air responds to Șā'ib's observations on the illusory relationship between unity and multiplicity by building an intertextual triangle with another line by his master Bīdil, where the latter subtly claims a right to his bewilderment (hayrat), noting that the "assault of the manifestation" (hujūm-i jilwa) of the Beloved is the same in the particle of dust and in the sun (Bīdil 1997, 2: 502). It is in this context that Krșna begins his discourse to the gopiss, asking, in the Persian rendering as well as in the Sanskrit original, if everything is well in Vraj (dar shahr$i$ shumā khayr-ast imshab) and trying to convince them to go back to their homes and their husbands (for example, "Everywhere a woman goes without the command of her husband (bi hukm-i shawhar) / she goes towards the hell (düzakh) of pain and misfortune"). As in the above-mentioned passages, the Persian text takes up many more lines than the Sanskrit and the strategies of poetical expression do not change. Krṣna speaks of the love for himself along the same lines outlined above, saying for instance that the hearts of the gopis "left themselves as waves" (hamchu mawj az $k h w i s h t a n$ shud), again recurring to the poetic tongue of his master to analyze the ontological paradoxes of erotic abandonment. ${ }^{32}$ Such examples of interpretative poetics can easily be multiplied. Without adding much to what has already been observed, I will provide just one last example. In the reply of the gopīs to Kṛ̣na, we may consider the use of the ubiquitous image of the sarw-i $\bar{a} z \bar{a} d$ ("the free-standing cypress") to textualize the devotional notion of Kṛ̣na as the eternal beloved "who vanquishes distress" (vrjinārdana):

tu khwud guftì ki har kas dil ba man dād

buwad az bār-i gham chūn sarw āzād (Amānat manuscript, folio 103b).

It was you who said that whoever gives his heart to me

will be free as a cypress from the burden of suffering.

Perhaps more peculiar, in terms of textual strategies, is the way in which the subjectivity of Amānat is infused into the text through his poetic persona. As a matter of fact, following Kṛ̣na's discourse to the gopiss, the author inserts a sevenline-long ghazal addressed, in the mațla', or opening line, to Kṛ̣na as the shäh-i khübān, "the king of the beauties," and canonically bearing the takhallus of the

\footnotetext{
32 The synesthetic implications of the use of the metaphorical image of the mawj, "wave," to indicate both illusory self-identification and self-annihilation are richly explored by Bīdil, who studies extensively the image in at least four ghazals where the term mawj is used as a radīf (Bīdil 1997, 1: 764, 766-67).
} 
author in the maqta', or closing line. The ghazal, which is introduced by the declaration "I have pronounced a ghazal regarding this situation" (ghazal guftam dar ān hälat), can be seen at the same time both as a lyrical commentary in the rarefied, decontextualized langue proper to the genre itself and as an attempt by the poet to intensify the voice of the gopis by becoming one of them in dramatic terms. Amānat is here the gopīs and the gopīs are Amānat, asking the "king of the beauties," Krṣna, in a perfect summa of the ma shīq and the ma 'büd, to "not leave me, by God, devoid of the ruby of your lips / because I am thirsty and have no other refuge but you" (Amānat manuscript: folio 103a). As in the above-mentioned passages from Bīdil's Chahār 'unșur and the tazkiras, the textual milieu in which the lyrical verses are inserted reveals the possibility of actualizing them, by including Kṛ̣na as an external referent (in this case, by far the dominant one), according to the same modalities I have described when speaking of the flute in the preceding paragraphs. More generally, this points to a possible, fascinating reception of the ghazal as a truly dramatic device both here and, for instance, in the rendering of the longing of the gopis for Krṣna in 10.30 and 10.31, where they are made to sing ghazals for the absent beloved. ${ }^{33}$

\section{Encoding and Decoding Kṛṣna: Multiple Referentialities}

Amānat's treatment of several other iconic episodes of the tenth skandha could and should of course be questioned in our search for the "terms of inclusion" of Krṣna's figure in the eighteenth-century Indo-Persian masnawi dimension; from the Shāhnäma-like demon-killing hero of several adhyāyas to the iconic divine child eating the mud and showing the universe in his mouth of 10.8, where Yaśodā (jasodhā) observes "at once what has a place and what is beyond place" (ba yak bār makān u lāmakān dìd), asking herself if "this child of mine is that very God / of whose presence no place is empty" (ìn pisar-i mā bāshad khudāy-ī / ki khālì nisst az way hich $j \bar{a}-\vec{\imath})$. It is perhaps more useful, however, to briefly focus on the long introductory section of the Jilwa-yi za $\bar{a}$, where some precious keys for the reading of the Persian Krṣna are provided and which will finally lead us-widening the perspective to the entire Persian Purāna by Amānat-to make some more general remarks on the reception and use of the text itself. ${ }^{34}$

The first twenty-one bayts of Amānat's preface are devoted to a poetical description of the formless and omnipervasive "essence" (zzāt) and its relationship with the material realm of immanence and experience. The weight of Bîdil's conceptual formulations can be felt, apart from the closely resembling style, especially if we consider the cosmogonic theories found in philosophical poems

\footnotetext{
33 This seems to somehow retrace the generic modalities of the dahnāma, "ten letters," or sīnama, "thirty letters," subgenre (Syed Hasan 1973), whose specific South Asian implications have been studied by Orsini (2006). Within the Jilwa-yi zāt, the lyrical form of the ghazal is often used to substitute direct speech while at the same time introducing the subjectivity of Amānat himself through the constant use of the takhallus, "pen-name."

34 An earlier, abridged version of the following paragraphs of this section has been published as a preview to this study (Pellò 2017a).
} 
such as 'Irfān and the Muhịt-i a 'zam. The latter, in particular, is sometimes quoted almost verbatim, as is the case when it deals with the process of manifestation of Pure Being. ${ }^{35}$ However, from this point onwards, the poetical theology of Amānat Rāy acquires more definite and specific tones. After having introduced the sudden manifestation of the "absolute beauty of the Beloved" (husn-i mutlaq-i yār) (1.22) the poet explains the cosmic event as follows in line 23:

khwud-i ü āyina shud khwud shakhṣ u timṣāl

hamān yakrangī-ash dar gardish-i hâal (Amānat manuscript: folio 2a)

He himself became the mirror, he became the person and the simulacrum, such is his unity of color in the revolution of states

The manifestation of the "absolute beauty of the Beloved" in line 22 is undoubtedly reminiscent of a famous ghazal by Hāfiz of Shīrāz where the "beauty" (husn) of the Beloved suddenly appears (tajalli zad) in the eternal (azal), creational event of love (Hāfiz 1983-84: 312). However, once again, Bīdil's experimentations are clearly observable even here, in the connection between "absolute beauty" (husn-i muṭlaq) and its reflection in the "mirror" (āyina), which leads to "selfidentification" (khwudbīn $\bar{l}$ ), explored in his Dīwān and his mașnawīs (for example, Bīdil 1997, 1: 406). The identification of the surface instrument (āyina "mirror"), the subject (shakhṣ "person"), and the object of vision (timșal "simulacrum") of line 23 is an actualized declension of the traditional monistic identification of the triad of love ( 'ishq), lover ('âshiq), and beloved ( $m a$ 'shüq). This kind of metaphorical identification had been repeatedly played upon by Bīdil himself, for instance with the auditive triad nay-naghma-mutrib / "flute-melody-minstrel" in the Muhitt-i a 'zam (Bīdil 1997, 3: 583); another great master of late seventeenth-century Mughal poetry, Nāșir 'Alī Sirhindī had even recast the triad in the field of paiting, with the identification of painting, painter, and painted image in a little studied mașnawi (see Pellò 2017b). Looking at Amānat's contemporaries, it is worth noting, as well, how a closely comparable image of the mirror is being used in eighteenth-century Iran by Hātif-i Ișfahān̄i (died 1783) to explore the Christian trinity in Persian poetical terms. In his well-known tarjī'-band he speaks in this regard of a "face reflected by three mirrors" (Hātif-i Ișfahān̄i 1968: 18). ${ }^{36}$ It is in this context of dense intertextual references, conceptual continuities, and aesthetic layerings of renovation that the specific notion of the trimūrti appears:

ba hasb-i khwāhish-i ān żāt-i yaktā nukhustin shud si shikl-i khāṣ paydā

yakī barmahā ki dar gulzār-i dunyā shud az nīlūfarī gul jilwafarmā

sabab-i ù shud pay-i ìjād-i 'ālam

ki bāshad bāqū-yi bunyād 'ālam

\footnotetext{
35 Consult, for instance, the use of the imagery revolving around the idea of taqaddus ("sanctity") of the muḥ̄t ("ocean") of Essence, and so on, in Amānat manuscript, folio 1b-2a and Bīdil 1997, 3: 583.

36 A classical English translation of the entire poem appears in Browne (1959: 292-97).
} 
digar ān jawhar-i i 'rā̇̇-i imkān

ba shikl-i bishn shud quwwat-i dah jān

siyum rudr ānki hamchūn turk-i bībāk

bisūzad kharman-i hastī chu khāshāk

'inān-i ikhtiyār-i būd u nābūd

ba dastishān buwad payvasta mawjūd

ba zạhhir garchi dar guftan judā-y-and

ba żāt-i khwīshtan ìnhā khudāy-and (Amānat manuscript, folios 2a-2b).

According to the will of that unique essence

as was convenient, three specific shapes appeared.

The first is Brahmā who, in the rose garden of the world, became manifest from a lotus flower.

His function was to bring the world into existence,

to make certain that the foundations of the world are stable.

Then, that pearl of the deployment of possibility

took the shape of Viṣnu, with the power of ten lives.

Third came Rudra, who, just like a fearless Turk

burns the harvest of existence like straw.

The reins of the choice between being and nonbeing

are always held in their hands.

And although they are separated in speech,

in their own essence they are God.

The iconographical textualization from which Brahmā appears (shud jilwafarmā) in the "garden of the world" (gulzār-i dunyā) and the even more striking reading of Rudra through the metaphor of the "fearless Turk" (turk-i bībāk) burning "the harvest of existence" (kharman-i hastī) are compelling examples of how the wealth of material provided by the inventory of the Persian literary hypertext can be used in projecting "new" material onto the hypertext itself. But they are also interesting examples of what the eternal "garden," which had been the active background for most lyrical events in Persian from the Samanid times, or the beautiful "fearless Turk" that had been destroying hearts from the very prehistory of the Persianate cosmopolis in Central Asia, ${ }^{37}$ can contain and evoke paradigmatically in an eighteenth-century Indo-Persian textual setting. In such a context, the unambiguous declaration of the fact that, for Amānat Rāy, Brahmā, Śiva, and Viṣnu "in their own essence are God," having the "rein of choice between being and non being" (it is worth highlighting that they are not read here under the generic heading of firishta "angels" very often applied in Indo-Persian texts), appears to be perfectly

37 On the metaphorical sociology of the Turk in Persian, see the introduction by Schimmel (1992: 13743). Interesting historical perspectives on the formative period are contained in Tetley 2009: especially $17-20$. 
naturalized in the canonical environment recreated in the poem. ${ }^{38}$ After having compared the function of the avatâra to that of a mirror which permits the observation of the absolute beauty (Amānat manuscript, folio $2 b)^{39}$ and after having enumerated and quickly described, in eleven bayts, the first seven avatāras (Matsya $=m \bar{a} h \bar{l}$ "fish"; Kūrma = kashaf"tortoise"; Varāha = Barah , Narasimha = shīr "lion"; Vāmana = Bāvan; Paraśurāma = Parsūūām; Rāma = Rām), Amānat at last comes to the object of his poem and, as we shall see, of his devotion. The relatively lengthy passage presenting the figure of Krṣna is worth translating in its entirety:

ba hashtum bār ān māh-i jahāngīr ba shikl-i krishn 'ālam kard taskhīr

shud az husn-i malīh-i khwud dar āfāq namakfarsāy-i zakhm-i jān-i 'ushshāq 'adīm al-mașal shud dar khūbī u nāz ki mānd az dīdan-ash muzhgān ba khwud bāz

ba mushtāqān numūd ān ḥusn-i mastūr ki khalq az jilwa-yi $\bar{u}$ gasht ma'mūr sar-i gīsūy-i mushkīn-ash tā bar $u$ dūsh pay-i mardum kamand-i gardan-i hüsh

kulāh-ash az parr-i țāwus bar sar ba khūbì rashk-i gardūn-i purakhtar hayā-rā hamzabān̄̄ bā nigāh-ash șabā dilbasta-yi zulf-i siyāh-ash

bahā-yi jān du la 'l-i nūshkhand-ash qiyāmat sāya-yi qadd-i buland-ash

ba tangī ghuncha mansūb-i dahān-ash zi gham bārīk mū bahr-i miyān-ash zi gawhar dar galū-yi $\bar{u}$ hamāyil hazārān dil ba yakjā karda manzil numāyān gasht hangām-i nazzā̄ra ba jayb-i mihr-i tābān șad sitāra guhar dar gūsh-i ān āyīnasīma ba māh-ī kard kawkab dast bālā kaf-i pā az șafā āyīna-yi gul zi naqsh-i pā numāyān sāghar-i mul

\footnotetext{
${ }^{38}$ Interestingly enough, Amānat uses here the poetic argumentation of the "three names" and "one essence" as Hātif-i Iṣfahānī (1968: 18) does when speaking of the Christian trinity in his famous tarjì'band.

39 A translation of the passage can be found in Pellò (2014: 34).
} 
shud az rang-i siyāh ān ḥusn mastūr

chu khāl-i mardumak sarmāya-yi nūr

ba ìn țal'at shud ān māh-i dilārā

jahān-rā dilnishīntar az suwaydā (Amānat manuscript, folio 3a).

The eighth time that world-conquering moon

subjugated the world in the shape of Kṛ̣na

That salty beauty reached the horizons

spreading salt on the wounds of the soul of the lovers

He became incomparable in beauty and coquetry so that eyelashes, looking at him, remained spread wide.

He showed that hidden beauty to those who were anxious to see him, so that creatures, through his epiphany, became prosperous.

His black curls, reaching his shoulders and his breast, were a snare catching the neck of people's intellect.

His hat, with a peacock feather on top, was the envy, for its beauty, of the sky full of stars.

Modesty spoke the same language of his gaze breeze was an intimate lover of his black locks.

His two sugar-chewing rubies had the price of life the Day of Resurrection is the shadow of his tall figure.

From his mouth descends every tiny blossom and the hair derives its thinness from his waist.

Because of the pearl hanging on his throat thousands of hearts have settled in one place.

At the moment of contemplation, there appeared one hundred stars in the bosom of a gleaming sun.

The pearl in the ear of that mirrorlike figure made a star to be imposed upon a moon.

The sole of his foot was pure as a mirror reflecting a rose from his footstep appeared a cup of wine.

That beauty was hidden in its black color, as the mole of the pupil of the eye is the capital of light.

With this aspect that world-embellishing moon became more close to the heart than the black stain.

Kṛ̣na is masterly described by recurring to the sarāpa (literally, "head to feet"), a little studied genre devoted to the detailed description of the beloved's physical beauty (Shafī'īyūn 2010) comparable to the Indic sikh-nakh (Busch 2011: 158) and 
which enjoys a certain diffusion in the late Indo-Persian and Urdu contexts. Thus, Krșna's beautiful figure is studied through a fashionable poetic lens, which serves well-via the multiple aesthetic citizenships of the sarāpā-sikh-nakh-in accommodating the traditional iconography of the avatāra within the textual environment of a Persian mașnawī. Usually, the technique is that of selecting a series of deeply codified images that can, by close formal analogies or easy contrasts, be readily applied to the "new" referent. In other words, except for the explicit mentioning of Krṣna as the object of the description, no reader educated in Persian literary culture would find anything uncanny. On the other hand, the description is at the same time precise in its adherence to the prevalent iconographies of Krṣna and shows, once again, how an eighteenth-century Vaiṣnava munsh $\bar{l}$-or for that matter any reader immersed in the multilingual and multiliterary milieu of late Mughal India-could recodify the centuries-old attributes, imagery, and metaphors employed here and how vast a world of referents (that is, Kṛnna multiplied in the mirrors of the multitude of named and anonymous beloveds of the Persian tradition) he could see in them. A most immediate example is the treatment of the color black. If the "black curls" represent a perfect iconographic parallel, the dark color of Kṛṣna's skin (which, by the way, is not at all unprecedented in Persian poetry ${ }^{40}$ ) is celebrated by its paradoxical transformation into a more acceptable white "capital of light," through the similitude with "the pupil of the eye," which in turn becomes a "black mole" - the latter evoking the lingering image of the black hind $\bar{u}$ with which it is often in a relationship of syntagmatic cohesion. ${ }^{41}$ In the line that follows, the "dark light" of Krṣna can be-thanks to the formal analogy provided by the round shapeat the same time a light full moon and the black stain (suwaydā) on the heart, which is a common figure of passionate love in Persian, deeply immersed in Șūfī culture (see for instance Sajjādī 1991: 111) and alluding to Muhammad as well. ${ }^{42}$ It would be fascinating, in this context, to explore the contextual pendants of the apparent contrast that is drawn by Amānat between a Turk (white) destroyer Rudra and a Hindu (black) sweet Kṛṣna (who is appropriately saucy like the dark gipsies / lüliyān of Hafez in a famous chiaroscuro ghazal). ${ }^{43}$ Here, however, I will limit myself to underline that the oxymoronic (for the Persian aesthetic tradition) blackness of the beautiful "beloved" Kṛṣna will be discussed one generation later in Qatīl's Haft tamāshā (a more than plausible audience for Amānat's work), where the Khatrī convert explains to his Iranian audience that: "In the beginning, Kanhaiyā was extremely beautiful, harmonious, and fair-colored (șabihalwān). At a later stage, he was bitten by a snake and became black, but his blackness was so well blended that

\footnotetext{
40 An example taken directly from the normative Dīwān of Hāfiz is where the beloved is described as having a wheat-colored cheek ('āriż-i gandumgūn); compare Hāfiz (1983-84: 134). Wheat-colored (that is, having the color of ripe wheat) is used in Persian as an image to convey the idea of a brownish color; a dark beauty in contrast with a white one.

41 A critical review of this celebrated trope can be found in Meneghini (1990).

42 The reference is to the well-known tradition based on the interpretation of Qurān 94: 1-3, the black stain (the symbolic mark of "darkness" on human hearts) on the heart of Muhammad was cleansed by the angels with snow when he was still a boy.

43 I am referring here to Hāfiz (1983-84: 22), sometimes read, in classical commentaries, as a reference to Tīmūr Lang.
} 
it captured every heart" (Qatīl 1875: 15). Amānat's sarāpā of black Kṛ̣na as the eternal Beloved leaves no space for technical observations in the doctrinal field. In particular, nothing is added as far as the special relationship between Krṣna and the "Essence" is concerned, especially if we consider the theological issues introduced by the interesting discussion on the trimürti seen above. A quick look at the later translation of a pivotal passage of the first skandha (as previously mentioned, completed in 1751 with all the other skandhas up to the ninth) is useful in gaining a more precise idea of who Krṣna is for Amānat Rāy. The key śloka 1.3.28, containing the famous line krṣnas tu bhagavān svayam "but Kṛ̣ṇa is God in person" is translated as follows:

dah avatār andar ìn bazm-i tilismāt

numāyān gashta yakyak partaw-i zāat

zuhūr-i kirishn 'ayn-i żāt-i yaktā-st

ki khwud-i sham'-i shabistān-i tamannā-st (Amānat Nd: 17).

The ten avatāras, in this symposium of magics, have shown, one by one, the beam of the Essence,

[but] the manifestation of Krṣna is the unique Essence in itself:

he is the very candle of the night-chamber of hope.

Amānat's translation is quite assertive in its identification of Kṛ̣na with the very essence of God. Particularly if read in the light of the above-mentioned identification of the trimūrti with God ( $b a \underline{z} \bar{a} t-i$ khwishtan inhā khudāy-and "in their own essence they are God"), the passage is transparent in stating the theological preeminence of Kṛ̣na (who subsumes, and thus precedes, the whole trimūrti) as the "unique Essence in itself." Especially noteworthy is the fact that the central Islamic notion of the unity/unicity of God (tawhidd), rendered by the use of the attribute yaktā "unique," is expressly applied here to the "manifest" (zuhür) figure of Kṛṣna. In Amānat's work, such doctrinal claims are flanked by devotional statements that are even more relevant if we consider the generic protocols of the Persian textual milieu in which they are inserted. This places the poetic figure of Amānat's Persian Kṛ̣na at the center of a much wider sociotextual framework, where the layered personality of an eighteenth-century Hindu munsh $\bar{l}$ acquires a new centrality. Following the autobiographical note, to which we shall return briefly, Amānat, as we have seen, inserts in the general description a note on the reasons and the occasion leading to the composition of the book (sabab-i nazm-i kitāb) (Amānat manuscript, folios 15a-18a). He first describes an archetypical night dominated by "restlessness" (bìtābì), "bewilderment" (hayrat), and the absence of real inspiration for both spiritual enlightenment and artistic creation (shikār-i ṣad khayāl-i püchmawhüm "the hunter of a hundred imaginations, without a single inspiration") in which he was wandering with his heart in turmoil like "the wave of a vortex" (mawj-i girdāb). Then, he tells the reader, suddenly a "rising star of happiness" ( $t \bar{a} l i{ }^{\prime}-i s a^{\prime} d$ ) came to his aid in the person of an admonishing guide urging him to awake. The nocturnal event, which is strikingly resemblant of the encounter between Amānat and his master recounted in the Tazkkira-yi Husaynī (see 
above), draws on ultraclassical models in a recognizable Bidilian style of diction. Here, however, the key figure leading to the literary-spiritual transformation in Amānat's life has a proper name:

buwad nām-ash zi fayż-i haqq dar āfāq

ba shuhrat bālakrishn-i kursmushtāq (Amānat manuscript, folio 16a)

His name is over the horizons for the grace of truth:

he is known as Bālakṛṣna the lover of soil

It is tempting to see an intertextual connection between this epiphany of Bālakṛ̣ṇa ("the infant Krșnạ") in Amānat's narrative and the life-changing interventions of "hindu boys" (hindūpisar) in the literary biographies of other Hindu poets of Persian such as Bhūpat Rāy Bīgham Bayrāgī, whose life is transformed thanks to a beautiful boy named Nārāyana (Narāyan). ${ }^{44}$ Be that as it may (the model for all these hindu figures of beautiful youths are, it should be born in mind, the Christian or Zoroastrian boys of classical Persian works ${ }^{45}$ ), the words addressed to Amānat by this Persian speaking Bālakṛṣna are very clear in terms of the devotion required. After a reprimand concerning the opportunity of making something "through which

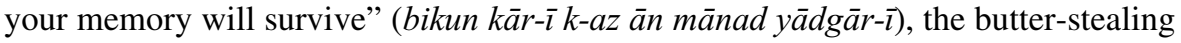
child from Vrindāban concludes his speech by telling Amānat:

ba nām-i khāṣ̦s-i ù lab āshnā kun

ba nām u nang-i ìn 'âlam du 'ā kun

agar dārī zabān dar kām gūy $\bar{a}$

kanhayā gū kanhayā gū kanhayā (Amānat manuscript, folio 17b).

Make your lips familiar with his proper name:

say a prayer for the honor of this world!

If you have, in your mouth, a tongue which is capable of speaking, say Kanhaiyā, say Kanhaiyā, say Kanhaiyā!

Amānat's response to this request, which leaves little room for doubt about the devotional nature of this dedication, confirms the author's will to identify his spiritual path and provide his literary effort with a definite religious commitment:

chu ìn nām az nishānī-yi ū shinīdam

ba maqșūd ki mībāyad rasīdam

zadam būsa ba dast-i rahbar-i khwīsh

qadam dar rāh-i $\bar{u}$ kardam sar-i khwīsh (Amānat manuscript, folio 17b).

When I heard this name from his image,

I reached the aim that was convenient

\footnotetext{
44 Some considerations regarding the motif, with special reference to the transitional literary character of Bīgham Bayrāgī, can be found in Pellò (2015: 144-45), which includes additional bibliography.

45 It would be fruitful to explore the apparent close connections of such tropes with the important subgenre known as shahrāshüb, where the "characters" of a textualized urban environment are described. On their South Asian counterparts, see Sharma 2004.
} 
I kissed the hand of my guide

and directed my steps to his path.

As a matter of fact, Amānat openly declares his devotion here and there in the text, for instance in the maqta ' (the closing bayt) of a ghazal inserted among the couplets of the translation of the very first adhyāya of skandha 1:

ba madh-i bādshahān kay buwad sar u kār-ash

ki guftugū-yi amānat ba 'ishq-i siyām buwad (Amānat Nd: 21)

He will never be occupied with the praise of the kings:

Amānat speaks only of the love for Śyāma.

As in the case of the self-identification with the gopis seen above, the author's literary persona expressed by the takhallus enters the text directly. In this bayt, Amānat sits together, so to say, with the object of his devotion, Krșna, who in the best 'irfāni tradition of the Persian lyrical genre, expressly subsumes the threefold function of the mamdūh (object of praise), ma'shüq (object of love), and ma'būd (object of devotion).

\section{A Kṛṣnaite Subjectivity in Persian}

A final quotation from the opening of Amānat's rendering of the first skandha will serve as an ideal introduction to the concluding remarks of this paper. Here the semantic density of the figure of the "idol" (but $)^{46}$ reveals all its weight as a key both to the inclusive poetic strategies of Amānat and to his discourse on textual selfidentification:

dar ìn butkhāna-yi hind ìn kitāb-ast

sawād-ash mashriq-i șad âftāb-ast

but-ī az har țaraf dar jilwa-yi nāz

barahmanpīsha u nāqūsdamsāz

tu-rā gar hast zawq-i butparastī

dar ìn manzil dar āȳ̄ u na ham hastī

dam-ī binwāz nāqūs-i faghān-ī

zi 'ishq-i but bayān kun dāstān-ī

jabīn kun șandalālūd-i ghulāmī

sawār dar sarw-i āzād-i mudāmī

shawad āyina-at șâf az kudūrat

bibīnī jilwa-yi ma 'n̄̄ zi șūrat

\footnotetext{
${ }^{46}$ The word but, originally meaning "Buddha" (consult Bailey 1931), has continuously been a pivotal one on the Persian poetical horizon since its very Central Asian beginnings, often connected with the image of the shaman < śramana, originally representing the Buddhist monk (compare Melikian-Chirvani 1974).
} 
chu șūratāfarīn bībīnī az dūr

sarāpāy-at shawad chūn mihr purnūr

shaw̄̄ mamnūn-i but har jā ki bāshī

barāy-i khwīshtan șūrat tarāshī

agar șuratparast-ī yār-i man bāsh

ba hayrat āshnā dar anjuman bāsh

sujūd-i but tu-rā gar dilnishīn-ast

khudā dar i 'tiqād-i man hamīn-ast (Amānat $\mathrm{Nd}$ : 2).

In this idol temple of India lies this book

whose black letters are the Orient of one hundred suns.

There is an idol that appears with its coquetry from every side, who has the ways of a Brāhmana, who is intimate with the bells.

Should you have a taste for idolatry

come into this house, unless you are already there!

Ring, for a while, the bells of a scream,

illustrate a story from the love for an idol!

Stain your front with the sandal of servitude,

on the free-standing cypress of eternity.

May your mirror be pure from every rust:

observe the epiphany of meaning in form!

When you see the creator of forms from faraway, the whole of you becomes full of light like the sun.

You become grateful to the idol everywhere you go and you carve an image for yourself.

If you are a worshiper of image, then be my companion:

come into the assembly, familiar with bewilderment.

If bowing down to the idol gladdens your heart, well, in my belief God is precisely this!

The actualized values of the centuries-old image of the but and the antinomian fashioning of the literary self as a butparast "idolater," while calling on the most codified metaphorical language of Persian Șūfī poetry (where the search for the blame of the conformist is a stylistic feature at least from Sanā'̄ century), should be contextually read as an articulated series of poetical utterances of subjectivity. ${ }^{47}$ As a matter of fact, this is no isolated example. An eloquent

\footnotetext{
47 Deliberately echoing Michail Bachtin but leaning especially on Francois Rastier's discussions on textual semantics and Sheldon Pollock's stances on philology and history, by "subjectivity" I mean here (and elsewhere in this paper) the sociotextual dimension of what the French scholar calls the "enunciative nucleus" as it is represented in the text and/or situated in the generic protocols and rules (Rastier 2001: 14-18).
} 
parallel comes from a slightly later original Persian hymn to Vārānāsīe the $K \bar{a} s h \bar{\imath}$ istūt (the title is a Persian phonetic adaptation of the Sanskrit Kāśs stuti), written in 1778, by the Kāyastha from Allāhābād Matan Lāl Āfarīn, which opens with the following lines:

hamd-i but-i butkada-yi lāmakan

ānki numūd ìnhama nām u nishān

bāng-i nukhust-i jaras-i ān maqām

kun fayakun-i pardakash-i khāṣṣ u 'āmm

farsh-i zamīn țālib-i pābūsī-ash

'arsh-i barīn rāhib-i nāqūsī-ash

barahman-i 'ishq parastār-i $\bar{u}$

kawn u makān ḥalqa-yi zunnār-i $\bar{u}$ (Āfarīn 1873: 2).

Praised be the Idol of the idol temple which has no place

the one who made manifest all these names and signs.

The very first ring of the bell of that high place

was the "Be!" which created every extant being.

The carpet of the Earth wishes to kiss his feet, the supreme Throne is the monk who tolls his bell.

The Brahman of love is his caretaker

and the whole universe is the buckle of his belt.

The challenging overture where the "Praise to the Idol" (hamd-i but) evokes a canonical Arabic-Islamic al-hamdu li-'llāh (the praise belongs to God), while substituting it, overlays an accumulation of the usual images of idolatry (the idol, the idol temple, the bell, the monk, the kissing of the feet, the Brahman, the zunnār) interacting with core Islamic theological notions such as the creative "fiat" kun fayakūn and the exalted Throne ('arsh-i barīn). As in the case of Amānat's devotion for Krṣna, it is the intersection with the (pretextualized) context that provides these rhetorical utterances with new semantics. In its closing lines, the author actually dedicates the Kâsh $\bar{\imath}$ istūt to the Brāhmanas. He deems himself a "Hindu secretary

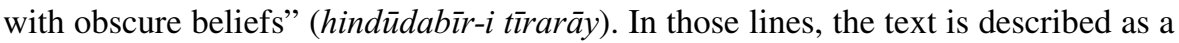
guide (or even a substitute) for a pilgrimage to the sacred city of Vārānāsī (Āfarīn 1873: 43). In this context, the autobiographical information provided by Amānat both in the Jilwa-yi zāt and in the Rāmāyan stands out for its self-promotional values, especially at the level of social and geographical appurtenance, in a productive play both with the literary persona of the author and with the multiple implied readers of the text. In the Jilwa-yi zāt, Amānat seems to be particularly interested in stressing that he was born in Lalpūr, which he was forced to leave due to a devastating flood and that he is a Khatri belonging to the Seth subcaste (folios 14b-15a). More than twenty years later, in the introduction to his Rāmāyan, he would once again describe his native Lalpūr hyperbolically as the "envy of the eternal paradise" (rashk-i khuld-i barīn) or the "garden of Iram" (bāgh-i iram), and 
he would also celebrate the history of his family (who had been there for one hundred and sixty years, beginning with his ancestor Gopāl), his own education there as a secretary and a poet of Persian, and the excellence of his fellow Khatrīs living there, described as "having the nature of Brāhmanas" (barahmansirishtān) and "reciters of the Veda" (bedkhwān) (Amānat 1872: 9-11).

In the same passage regarding the Smārtas mentioned at the beginning of this paper, Qatīl observes, after having mentioned the "various images" (șürathā-yi mukhtalif) of Viṣnu's manifestation, that the "Arabic translation of avātar is mazhar (place of manifestation), and [the Smārtas] are so much in accordance with Șūfîsm (tașawwuf) that they consider each image (șürat) the mazhar of God, and indeed God himself" (1875: 11). One is tempted to ask what was the actual circulation, reception, and use of works such as the Jilwa-yi żăt and the Srī Bhägavat within the multilayered and by no means neutral sociotextual backgrounds implied here as well as in Amānat's or Āfarīn's self-descriptions. ${ }^{48}$ Or in both plainer and bolder terms: were Amānat's celebrated fellow Khatrīs and the other eighteenth-century North Indian secretaries writing in Persian who textualized themselves as hinduwān actually reading such texts, and how? Some precious preliminary indications come directly from the manuscript tradition. As the colophon informs us, the very manuscript on which the present paper is mainly based was copied in $1772^{49}$ in the town of Farrukhābād (balada-yi Farrukhābād) by a certain Shīv Sahāe, who hastens to tell the reader that he resided in the qasba of Maham and describes himself as a zunnārdār, that is, a "bearer of the zunnār" (Amānat manuscript, folio 499b). Moreover, the same Shīv Sahāe specifies that the book-which contains, it may be useful to remember here, more than eighteen thousand mașnawi lines-was copied in just a few days from another copy, owned by a certain Lāla Jagannāth, the son of Sadānand, a Khatrī living in Shāhjahānpūr. Thus, the Jilwa-yi zāat, written in Delhi by a Khatrī bhakta from Lalpūr, circulated among eighteenth-century munshīs from Uttar Pradesh in a non-courtly geography. Shīv Sahāe would have taken to the qașba of Maham the book he had copied in Farrukhābād from the copy belonging to Lāla Jagannāth, who was in turn based in Shāhjahānpūr. The very size of the manuscript, a small portable book $(16 \times 8 \mathrm{~cm})$ particularly if compared to the enormous number of lines it contained, is also an explicit indication of its private use. Among the most notable features of the manuscript is the fact that the first page bears as a dedicatory heading the unmistakable invocation Srīkrishnāyanamah, in place of the customary Islamic basmala (Amānat manuscript, folio 1b). Again, this is not at all an isolated case; if we look beyond the Jilwa-yi zāt, similar invocations

\footnotetext{
${ }^{48}$ In the absence of extensive philological explorations and careful textual analyses, an articulated discussion on the reception of these texts is still beyond our reach. However, considering their poetic refinedness, the fact that they were among the first books to be printed in North India and some external evidence-such as the stamp from the North-West Frontier Province on the Sri Bhägavat copy in the British Library or Qatīl's observations from Nawābī Lucknow-one can tentatively suppose that they were read well beyond the immediate circle of the disciples of Bīdil and the world of the Hindu munshī. It might not be too fanciful then to imagine a truly transregional readership, including West Asian travelers as well as Rāj officials (consult also Pellò 2014: 41). To avoid any premature enthusiasm, however, it is worth highlighting that, until the present, I have not been able to locate any copy of Amānat's work (neither manuscript nor printed) in Iranian collections.

49 Precisely during the beginning of the month of Ramaḍān 1186, corresponding to late November 1772.
} 
to Krṣna (but also Ganeśa and other deities) take the place of the traditional basmala. These can be found in several manuscripts authored and/or copied by Persian-writing Hindu intellectuals, beginning at least in the 1670s. Just to name a few scattered examples, in reverse chronological order: the abridged Persian version entitled Sirāj al-tarīq of the Nasiketopakhyāna by the Khatrī from Sialkot Rūp Narāyan (a Gopāl devotee flourishing at the beginning of the eighteenth century), copied in 1767, bearing the invocation srī gopāl u srī kirishn sahāe (Rūp Narāyan manuscript, folio 1a); the Mughal Srī Bhāgavat Mahāpūrān, copied in 1759 in Shāhābād by a scribe named Rajkaran, bearing Srī Ganeshāyanamah, just like the Purān Srì Bhāgavat, copied in 1726 and held as well in the Aligarh collection (see Zaidi 1994: 60-61, 69); and, most notably, the volume containing the Persian Bhagavad Gìtā, Gìtāsārā, and Bhāgavata Purāna, copied in 1080/1670 in a compact format $(21.5 \times 14.5 \mathrm{~cm})$, where each of the three texts is introduced with the dedication Srī krishna jayo (Subhā Chand manuscript, folios 44b, 88a, 92b) and where the name of scribe Subhā Chand is recognizable, for instance at folio 91b, where he defines himself as a Kāyastha Srīvastava from Gwālior. In this latter manuscript, the invocation Srī krishna jayo is scattered throughout the text itself (especially in the Git $\bar{a} s \bar{a} r \bar{a}$, where it appears frequently in red ink) and the invocation Hanuman jayo sahāe is also present (folio 319a); notably enough, on the first page of the Bhāgavata Purāna the eulogy Srì krishna jayo is quite eloquently placed above the basmala. ${ }^{50}$

In the subtitle of his brilliant pamphlet Filologia e libertà, the Italian classicist and historian Luciano Canfora calls philology "the most subversive of disciplines." ${ }^{, 1}$ Unequivocally endorsing such a statement, I suggest that a philological study of Persian works such as the Jilwa-yi zāt and several others of its kind, as well as their transmission and reception, would assist us in decisively subverting many die-hard essentializations - first of all, in terms of linguistic boundaries and wallsand presentist views regarding premodern and early modern Islamicate South Asian cultures. While showing that it might be useful to begin talking of a largely unexplored Vaiṣnava-Kṛ̣ṇaite current within Indo-Persian literature, whose main producers, broadcasters, and consumers were apparently the Persian-educated members of Hindu scribal groups, such profound excavations challenge as well many preconceived views regarding the use of the texts, projecting these works onto a noncourtly provincial background of capillary circulation. Persian, once more proving its plasticity as an inclusive platform, should thus be numbered among the other "languages" of Krṣnaite textuality, in a nonpurist, mutual perspective. In other words, if Amānat Rāy's as well as other comparable Persian remakes of the Bhāgavata Purāna might be even too easily (and predictably) categorized, in Lawrence Venuti's fashionable terms, as "domesticating" translations (for instance, Venuti 1995: passim), one would question to which domesticity the domestication is supposed to lead. As a matter of fact, texts such as the Jilwa-yi zāt-

\footnotetext{
${ }^{50}$ Such interesting data throw new light on polemic declarations such as those by the eighteenth-century tažkira writer "Abd al-Waḥ̣āb Iftikhār on Hindus writing in Persian, who criticizes their work precisely because they are "devoid of the brilliant glare emanating from the eulogies of the Lord of the Prophets" (cited in Pellò 2014: 22).

51 "La più eversiva delle discipline" (consult Canfora 2008).
} 
programmatically endowed with a rich semantic plasticity-seem to domesticate Krṣna in the ambit of Persian literary culture while at the very same time pointing to the existence of parallel, enlarged conceptual/performative grammars through which they could be read, thus providing the tools for a noncontrastive domestication of Persian to certain aspects of Krșnaite bhakti. From the point of view of the Persianate Hindu munshī, Krṣna is comfortably at home in Shīrāz as much as in Mathurā, and there is no need to "take him back" anywhere, since both places truly belong to the realm of the Indo-Persian writer. A properly philological exploration of the interstices of such a text-world will certainly serve as a fine tool for integrating and rethinking a number of narratives regarding the sociosemiotic articulation of modern South Asian religious "identities."

\section{References}

'Abd Allāh, Sayyid. 1992 [1942] Adabiyāt-i fārs̄̄ mẽ hindu'õ kā hișṣa. Delhi: Anjuman Taraqqi-yi Urdū. Abdul Ghani. 1960. Life and Works of Abdul Qadir Bedil. Lahore: Publishers United.

Āfarīn, Matan Lāl. 1873. Kāshī istut. Lucknow: Navalkishor.

Ahmad, Aziz. 1964. Studies in Islamic Culture in the Indian Environment. Oxford: Clarendon Press.

Alam, Muzaffar and Sanjay Subrahmanyam. 2004. "The Making of a Munshi." Comparative Studies of South Asia, Africa and the Middle East 24, 2: 61-72.

Alam, Muzaffar and Sanjay Subrahmanyam. 2012. "Eighteenth-Century Historiography and the World of the Mughal Munshī." In Muzaffar Alam and Sanjay Subrahmanyam, Writing the Mughal World: Studies on Culture and Politics, 396-428. New York: Columbia University Press.

Amānat, Lāla Amānat Rāy. 1868. Srī Bhāgavat iskand 11. Kanpur: Navalkishor.

Amānat, Lāla Amānat Rā. 1870. Srī Bhāgavat iskand 10. Kanpur: Navalkishor.

Amānat, Lāla Amānat Rāy. 1872. Rāmāyan-i fārsī. Lucknow: Navalkishor.

Amānat, Lāla Amānat Rāy. N.d. Srī Bhāgavat. Kanpur: Navalkishor.

Amānat, Lāla Amānat Rāy. Manuscript. Jilwa-yi żāt. Islamic 270. India Office Library, London.

Anūsha, Hạan, ed. 2001 (1380 Sh). Dānishnāma-yi adab-i fārsī: Adab-i fārsī dar shibh-i qārra (Hind, Pākistān, Banglādish). One Volume in 3 Parts. Tehran: Wizārat-i Farhang wa Irshād-i Islāmī.

Bailey, H. W. 1931. “The Word 'But' in Iranian.” Bulletin of the School of Oriental Studies 6, 2: $279-83$.

Baqir, M. 2011 [1989]. "Amānat.” Encyclopaedia Iranica. Available at: http://www.iranicaonline.org/ articles/amanat-monsi-amanat-ray-amanat-12th-18th-century-poet-in-persian.

Bhāgavata Purāṇa. 1996 [1971]. Śrīmad Bhāgavata Mahāpurāṇa (with Sanskrit Text and English Translation) (trans. C. L. Goswami). Part 2. Gorakhpur: Gita Press.

Bīdil, 'Abd al-Qādir. 1965-66 (1344 Sh). Kulliyāt (ed. Kh. Khalīlī). Volume 4. Kabul: Da Puhane wizārat, da Dār al-ta' līf riyāsat.

Bīdil, 'Abd al-Qādir. 1997 (1376 Sh). Kulliyāt-i Bīdil-i Dihlawī (eds. 'A. Bihdārwand and P. 'A. Dākānī). 3 volumes. Tehran: Ilhām.

Browne, Edward G. 1959 [1924]. A Literary History of Persia. Volume 4: Modern Times (1500-1924). Cambridge: Cambridge University Press.

Busch, Allison. 2011. Poetry of Kings: The Classical Hindi Literature of Mughal India. New York: Oxford University Press.

Canfora, Luciano. 2008. Filologia e libertà: La più eversiva delle discipline, l'indipendenza di pensiero e il diritto alla verità. Milano: Arnoldo Mondadori Editore.

Chalisova, Natalia. 2012 [2004]. "Hosn-e Ta'lil." Encyclopaedia Iranica. Available at: http://www. iranicaonline.org/articles/hosn-e-talil-lit-beauty-of-rationale.

Debī Prashād. 1885. Tažkira-yi āṣār al-shu 'arā-yi hunūd: hindū shā'irõ kā urdū kalām. Delhi: Mața'-i Riżwī.

Ernst, Carl W. 2003. "Muslim Studies of Hinduism? A Reconsideration of Arabic and Persian Translations from Indian Languages." Iranian Studies 36, 2: 173-95. 
Ethé, Hermann. 1903. Catalogue of the Persian Manuscripts in the Library of the India Office. Volume 1. Oxford: Printed for the India Office by Horace Hart.

Habībī, Zuhra and 'Alī Bābāyī. 2012-13 (1391 Sh). Ramzhā-yi bīpāyān-i āyīna: Ramzhā-yi āyīna dar 'àlam-i ma 'rifat wa hikmat wa 'irfān. Tehran: Mawlā.

Ḥāfiẓ. 1983-84 (1362 Sh). Dīwān (ed. P. N. Khānlarī). Volume 1. Revised Second Edition. Tehran: Khwārizmī.

Hātif-i Iṣfahān̄i. 1968 (1347 Sh). Dīwān-i Hātif-i Ișfahānī (ed. Waḥīd Dastgirdī). Tehran: Ibn-i Sīnā.

Hindī, Bhagwān Dās. 1958. Safina-yi hindī: Tažkira-yi shu 'arā-yi fārsī (ed. Sayyid Shāh Muḥammad 'Ațā al-Raḥmān 'Ațā Kākwī). Patna: Institute of Post-Graduate Studies and Research in Arabic \& Persian.

Husaynī, Mīr Husayndūst Sunbhalī. 1875. Tazkkira-yi Husaynī. Lucknow: Navalkishor.

Jāmī, 'Abd al-Raḥmān. 1998 (1377 Sh). Mașnawī-yi 'āshiqāna wa 'ārifāna-yi Yūsuf wa Zulaykhāa: az mașnawīhā-yi Haft awrang (ed. Nāșir Nīkūbakht). Tehran: Āwā-yi Nūr.

Keshavmurthy, Prashant. 2016. "Bīdil's Portrait: Asceticism and Autobiography." Philological Encounters 1: 313-46.

Keshavmurthy, Prashant. 2018. “Translating Rāma as a Proto-Muhammadan Prophet: Masīḥ’s Mašnavì-yi Rām va Sìtā.” Numen 65: 1-27.

Kovacs, Hajnalka. 2013. “ 'The Tavern of the Manifestation of Realities.' The Masnavī Muhịt-i A zam by Mīrzā 'Abd al-Qādir Bedil (1644-1720).” PhD Dissertation, University of Chicago.

Maurice, Thomas. 1798. The History of Hindostan; its Arts, and its Sciences, as Connected with the History of the Other Great Empires of Asia, During the Most Ancient Periods of the World. Volume 2. London: H. L. Galabin.

Melikian-Chirvani, Asadullah Souren. 1974. "L'évocation littéraire du bouddhisme dans l'Iran musulman." In Jean Aubin, ed., Le monde iranien et l'islam: sociétés et cultures, 2: 1-72. Gèneve: Librairie Droz.

Meneghini, Daniela. 1990. "Le turc et l'indien dans les ghazals de Hafez." Annali di Ca' Foscari 29.3, Serie Orientale 2: 151-67.

Mujtabai, Fathullah. 1978. Aspects of Hindu-Muslim Cultural Relations. Delhi: National Book Bureau.

Munzaw̄̄, Aḥmad. 1985. Fihrist-i mushtarak-i nuskhahā-yi khaț̣īyi fārsī-yi Pākistān. Volume 4. [Lahore]: Markaz-i taḥqīqāt-i fārsī-yi Īrān wa Pākistān.

Naqsh 'Alī. 1992 [1977]. Bāgh-i ma 'ān̄̄ (ed. 'Ābid Riżā Bīdār). Patna: Khuda Bakhsh Oriental Public Library.

Orsini, Francesca. 2006. "Love letters." In Orsini, Francesca, ed., Love in South Asia: A Cultural History, 228-58. Cambridge: Cambridge University Press.

Orsini, Francesca. 2014. “ 'Krishna is the Truth of Man’: Mir ‘Abdul Wahid Bilgrami’s Haqā 'iq-i Hind̄̄ (Indian Truths) and the Circulation of Dhrupad and Bishnupad." In Thomas de Bruijn and Allison Busch, eds., Culture and Circulation: Literature in Motion in Early Modern South Asia, 222-46. Leiden: Brill.

Pellò, Stefano. 2012. Tüțiyān-i hind: specchi identitari e proiezioni cosmopolite indo-persiane (16801856). Firenze: Società Editrice Fiorentina.

Pellò, Stefano. 2014. "Persian as a Passe-Partout: The case of Mīrzā 'Abd al-Qādir Bīdil and His Hindu Disciples." In Thomas de Bruijn and Allison Busch, eds., Culture and Circulation: Literature in Motion in Early Modern South Asia, 21-46. Leiden: Brill.

Pellò, Stefano. 2015. "Drowned in the Sea of Mercy: The Textual Identification of Hindu Persian Poets from Shi ‘i Lucknow in the Tazkira of Bhagwān Dās 'Hindī'." In Vasudha Dalmia and Munis D. Faruqui, eds., Religious Interactions in Mughal India, 135-58. Delhi: Oxford University Press.

Pellò, Stefano. 2016. "A Linguistic Conversion: Mīrzā Muhammad Hasan Qatīl and the Varieties of Persian (ca. 1790).” In Stefano Pellò, ed., Borders: Itineraries on the Edge of Iran, 203-40. Venezia: Edizioni Ca'Foscari.

Pellò, Stefano. 2017a. “A Persian Praise of Krishna: A Note on the Preface of Amānat Rāy's Bhāgavața Purāna." Studi e materiali di storia delle religioni 83, 2: 573-82.

Pellò, Stefano. 2017b. "The Portrait and Its Doubles: Nāșir 'Alī Sirhindī, Mīrzā Bīdil and the Comparative Semiotics of Portraiture in Late Seventeenth-Century Indo-Persian Literature.” Eurasian Studies 15, 1: $1-35$.

Qatīl, Mirzā Ḥasan Muhammad. 1875. Haft tamāshā. Lucknow: Navalkishor.

Raḥm 'Alī Khān Īmān. 2007 (1386 Sh). Muntakhab al-laṭā'îf (eds. Ḥ. 'Alīzāda and M. 'Alīzāda). Tehran: Intishārāt-i Tahūrī.

Rastier, François. 2001. Arts et sciences du texte. Paris: Presses Universitaires de France. 
Ridgeon, Lloyd. 2012. "Naqshbandī Admirers of Rūmī in the Late Timurid Period." Mawlana Rumi Review 3: 124-68.

Rūmī, Jalāl al-Dīn. 1996 (1375 Sh). Mașnawī-yi ma ‘naw̄ì (ed. Q. Khurramshāhī). Tehran: Intishārāt-i Nāhīd.

Rūmī, Jalāl al-Dīn. 1999 (1378 Sh). Kulliyāt-i Dīwān-i Shams (ed. B. Z. Furūzānfar). Tehran: Bihzād.

Rūp Narāyan. Manuscript. Sìrāj al-tarīq. Habib Ganj Collection 50/145 (B). Maulana Azad Library, Aligarh.

Sa'dī. 1954 (1333 Sh). Kulliyāt-i Shaykh Sa'dī (ed. M. 'A. Furūghī). Tehran: Intishārāt-i 'Ilmī.

Șā'ib-i Tabrīzī. 1985-95 (1364-74 Sh). Dīwān-i Șā’ib-i Tabrīzì (ed. M. Qahramān). 7 volumes. Tehran: Intishārāt-i 'ilmī wa farhangī.

Sajjādī, Sayyid Ja'far. 1991 (1370 Sh). Farhang-i iṣtilāhāt wa ta 'bīrāt-i 'irfānī. Tehran: Țahūrī.

Salīm, Muhammad 'Alī Hasan Khān. 1878. Șubḥ-i gulshan. Bhopal: Maṭba'-i Shāhjahān.

Schimmel, Annemarie. 1992. A Two-Colored Brocade: The Imagery of Persian Poetry. Chapel Hill: University of North Carolina Press.

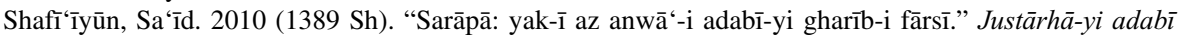
43: 147-74.

Sharma, Shriram. 1982. A Descriptive Bibliography of Sanskrit Works in Persian. Hyderabad: Abul Kalam Azad Oriental Research Institute.

Sharma, Sunil. 2004. "The City of Beauties in the Indo-Persian Poetic Landscape." Comparative Studies of South Asia, Africa and the Middle East 24, 2: 73-81.

Sharma, Sunil. 2012. "Representation of Social Groups in Mughal Art and Literature: Etnography or Trope?" In Alka Patel and Karen Leonard, eds., Indo-Muslim Cultures in Transition, 17-36. Leiden: Brill.

Subhā Chand. Composite Manuscript. Cod. Pers. 351. Bayerische Staatsbibliothek, München.

Syed Hasan. 1973. "Sí-Námehs in Persian." Indo-Iranica 26, 1: 62-71.

Tetley, G. E. 2009. The Ghaznavid and Seljuq Turks: Poetry as a Source for Iranian History. New York: Routledge.

Truschke, Audrey. 2016. Culture of Encounters: Sanskrit at the Mughal Court. New York: Columbia University Press.

Venuti, Lawrence. 1995. The Translator's Invisibility: A History of Translation. London: Routledge.

Waḥshī-yi Bāfqī. 2001 (1380 Sh). Dīwān-i Wahhshī-yi Bāfqī (ed. Ḥ. Āzaarān). Tehran: Amīr Kabīr.

Zaidi, Shailesh, comp. 1994. Hinduism in Aligarh Manuscripts: Descriptive Catalogue of Persian Mss. of Maulana Azad Library, A.M.U., Aligarh on Hindu Legends, Philosophy \& Faith. Patna: Khuda Bakhsh Oriental Public Library.

Zipoli, Riccardo. 1997. "Farrokhi, Hafez, Sa'eb: tre stili a confronto." In Riccardo Zipoli and Gianroberto Scarcia, eds., Mirzâ 'Abdolqâder Bidel: Il canzoniere dell'alba, 15-36. Milano: Ariele.

Zipoli, Riccardo. 2009. "Poetic Imagery." In J. T. P. de Bruijn, ed., General Introduction to Persian Literature, 172-232. London: I. B. Tauris.

Zipoli, Riccardo and Asadollah Habib. 2013. "Reflexões sobre o espelho em Bidel: Paráfrases e comentários." Ayiné 1: 171-201. 